\title{
PROTEÇÃO DA PRIVACIDADE NO CONTRATO DE TRABALHO: DA NORMATIZAÇÃO LEGAL A SITUAÇÕES DE CONFLITOS

\author{
PRIVACY PROTECTION ON THE LABOUR CONTRACT: FROM THE LEGAL \\ NORMATIZATION TO CONFLICT SITUATIONS
}

\author{
Regina Linden Ruaro" \\ Eugênio Hainzenreder Junior ${ }^{* *}$
}

Resumo: A relação de emprego sofreu profundas modificações no final do século XX, revelando uma mudança de paradigma manifestada em um novo ambiente de trabalho centrado no conhecimento e na informação. A globalização e as novas tecnologias representaram o desenvolvimento do universo empresarial. Tal evolução fez com que os antigos sistemas de organização do trabalho nas empresas se transformassem, surgindo também novas formas de conflitos, envolvendo os direitos da personalidade do empregado, especialmente em razão da vigilância e de novos meios de controle patronal. Ao mesmo tempo que se aplica o direito constitucional da privacidade do trabalhador no ambiente laboral, o poder diretivo e o direito de propriedade do empregador são direitos indissociáveis da relação de emprego. Da mesma forma que o poder de direção não pode justificar o desrespeito à privacidade do trabalhador, a garantia dos direitos fundamentais não deve servir para viabilizar o cometimento de irregularidades pelo empregado. Neste artigo, portanto, objetivou-se apresentar um estudo sobre o direito à privacidade do empregado, bem como uma análise do poder diretivo do empregador, demonstrando, com base na doutrina e na jurisprudência, algumas premissas na solução de conflitos envolvendo a realização de revistas em trabalhadores, o uso de câmeras de vídeo como fiscalização no ambiente de trabalho e o monitoramento da correspondência eletrônica.

Palavras-chave: Direito do trabalho. Fiscalização. Empregado. Privacidade. Poder diretivo.
Abstract: The employment relationship has undergone deep changes in the late twentieth century, revealing a paradigm shift manifested in a new working environment centered on knowledge and information. Globalization and new technologies performed the development of the business universe. This evolution has made the old systems of business organization of labor work to be transformed, also emerging new forms of conflicts involving personality rights of the employee, in particular because of monitoring and new forms of employer control. At the same time that the constitutional right of privacy in the labor environment is applied, the management power and the property rights of the employer may not be dissociate from the employment relationship. In the same way that the direction power cannot justify the disrespect to worker's privacy, the guarantee of fundamental rights cannot be used to enable the commitment of irregularities by the employee. In this article, therefore, the aim was to present a study about the right to privacy of the employee as well as an analysis of the direction power of the employer, demonstrating, based on the doctrine and jurisprudence, some assumptions in the solution of conflicts involving the realization of frisks on workers, the use of video cameras and surveillance in the workplace and monitoring of electronic mail.

Keywords: Labor law. Monitoring. Employee. Privacy. Management power.

\footnotetext{
"Doutora em Direito pela Universidad Complutense de Madrid; Pós-doutora pelo Centro de Estudios Universitarios, San Pablo de Madri; Professora titular da Pontifícia Universidade Católica do Rio Grande do Sul; Av. Ipiranga, 6681, Partenon, 90619-900, Porto Alegre, Rio Grande do Sul, Brasil; ruaro@pucrs.br

* Doutorando do Programa de Pós-graduação em Direito da Pontifícia Universidade Católica do Rio Grande do Sul; Bolsista da CAPES - Proc. n. 3948/15-3. Professor da Pontifícia Universidade Católica do Rio Grande do Sul; Av. Ipiranga, 6681, Partenon, 90619-900, Porto Alegre, Rio Grande do Sul, Brasil; eugenio.junior@pucrs.br
} 


\section{Introdução}

O tema do direito fundamental à privacidade nas relações de trabalho é instigante e provocador de polêmicas e controvérsias, na medida em que esta discussão não se trata apenas de abranger os limites dos poderes do empregador na relação de emprego, mas também de analisar o direito à vida privada do trabalhador no ambiente de trabalho atual.

É sabido que a relação de emprego sofreu profundas modificações no final do século XX, revelando uma mudança de paradigma manifestada em um novo ambiente de trabalho centrado no conhecimento e na informação. A globalização e as tecnologias de informação e comunicação (TICs) representaram o desenvolvimento do universo empresarial. Tal evolução fez com que os antigos sistemas de organização do trabalho nas empresas se transformassem, cedendo lugar a novas formas de conflitos que envolvem os direitos da personalidade do empregado, sobretudo em razão da vigilância e da novel forma de controle patronal.

Se o cidadão comum já se encontrava extremamente vigiado pelos novos adventos tecnológicos, conforme anunciado na obra Nineteen Eigthy Four - 1984, de George Orwell, em que havia a figura do Big Brother, que tudo via e controlava, justificando o lema Big Brother is watching you (o Grande Irmão te vigia), tal realidade se torna ainda mais temerária diante da relação de emprego, em que uma das partes, o empregado, é considerada hipossuficiente e deve um permanente estado de subordinação, enquanto a outra, o empregador, detém o poder de direção e assume os riscos da atividade econômica.

Os tempos atuais, em face de tal realidade, estão a desejar um profundo debate acerca do espaço privado do empregador e do empregado capaz de possibilitar o advento de normas capazes de dirimirem conflitos nunca antes pensados.

Dessa forma, no presente trabalho objetivou-se analisar o direito à privacidade do empregado no contrato de trabalho sob o prisma do poder diretivo do empregador, verificando-se, ao final, algumas situações práticas em que os interesses patronal e obreiro entram em rota de colisão, quais sejam, os procedimentos de revistas em empregados, a fiscalização por câmeras de vídeo e o monitoramento do correio eletrônico.

A metodologia buscou o mapeamento e a investigação bibliográfica, assim como a apreciação dos dispositivos constitucionais e infraconstitucionais referentes ao tema, recorrendo-se também à análise jurisprudencial, com a finalidade de obter os subsídios teóricos para a análise do problema proposto. O método adotado foi o dedutivo, tendo como premissa maior os direitos fundamentais previstos na legislação brasileira, bem como o método dialético, uma vez que a questão é objeto de constante debate, sendo, pois, necessário o confronto de correntes doutrinárias e a normativa brasileira. 


\section{Do direito à privacidade: proteção e regramento legal}

O Estado democrático de direito tem como um de seus fundamentos básicos a dignidade da pessoa humana. Partindo-se desse valor como princípio fundamental, foi assegurada ao indivíduo a não intervenção do Estado ou de qualquer terceiro na sua esfera privada. Entre os direitos da personalidade mais importantes na tutela da pessoa humana, situam-se os direitos à intimidade e à vida privada, que, hodiernamente, cada vez mais são colocados em pauta no ambiente de trabalho.

O "direito a estar só" ou o "direito de ser deixado em paz" há muito é objeto que instiga a pesquisa, dada a variedade de dimensões em que pode ser analisado. ${ }^{1} \mathrm{~A}$ Bíblia Sagrada, há mais de 2000 anos, já registrava a necessidade de solidão do homem como um momento voltado à oração e à reflexão sobre a palavra de Deus, que leva ao crescimento espiritual, conforme disposto em Mateus 6:5. ${ }^{2}$

No feudalismo, a intimidade passou a ganhar espaço na casa da família, por meio da separação da vida da comuna dos interesses pessoais, como a intimidade do sono, do almoço e da religião. Tal noção recebeu maior dimensão na família burguesa pela ideia do ensimesmamento em casa e de cada indivíduo em seu quarto como condição de habitabilidade (DONEDA, 2000, p. 113). Com efeito, o pensamento da burguesia da Inglaterra do século XVII estabeleceu o princípio da inviolabilidade de domicílio, evoluindo da necessidade da propriedade privada para a necessidade da vida privada, já que a característica burguesa dessa época era o isolamento e o individualismo na propriedade privada (SIMÓN, 2000, p. 71).

Não obstante a primeira noção mais concreta do direito à privacidade ocorreu nos Estados Unidos, em 1890, quando o advogado Samuel Warren, integrante da sociedade burguesa norte-americana, teve divulgadas na imprensa informações particulares sobre o casamento de sua filha. Tal situação gerou profunda irresignação por parte dele, ensejando, com Louis Demitis Brandeis, a publicação do artigo The Right to Privacy, na Harvard Law Rewiew, conhecido como Ensaio de Warren e Brandeis (TEIXEIRA; HAEBERLIN, 2005, p. 39). Por meio desse trabalho, os autores pretendiam alertar a sociedade sobre a interferência da imprensa na vida das pessoas, apontando, já nessa época, a tecnologia como provedora de meios que possibilitavam a intromissão indevida em assuntos privados. Além disso, tiveram o mérito de proporcionar uma análise da privacidade também no que se relaciona à pessoa humana, isto é, como valor moral e não apenas sob o enfoque da propriedade burguesa. Para eles, a proteção de valores humanos era tão importante como a tutela sobre os bens materiais (LIMBERGER, 2007, p. 205).

\footnotetext{
Sobre o assunto, Miguel (1995 apud BARROS, 1997, p. 119) leciona que a intimidade pode ser vista sob três dimensões: como fenômeno (fator socioeconômico), como idéia (fator cultural) e como direito (fator político-jurídico). 2 "Quando orares, entra no teu quarto, fecha a porta e ora ao teu Pai em segredo; e teu Pai, que vê num lugar oculto, recompensar-te-á.”
} 
Em 1928, agora como juiz da Suprema Corte Americana, Louis Brandeis pôde colocar em prática seu artigo The right to privacy, no julgamento do caso Olmstead v. U.S 277 U.S. 438, em que, embora seu voto tivesse sido vencido, sustentou que o direito de ser deixado só é "[...] o mais abrangente dos direitos e o direito mais valioso do cidadão." (TEIXEIRA; HAEBERLIN, 2005, p. 39).

A necessidade de proteção à privacidade, posteriormente, em 1948, foi objeto da Declaração Universal dos Direitos Humanos, no artigo 12, in verbis: "Ninguém será sujeito a interferências na sua vida privada, na sua família, no seu lar ou na sua correspondência, nem a ataques a sua honra e reputação. Toda pessoa tem direito à proteção da lei contra tais interferências ou ataques."

No âmbito internacional do trabalho, em 1996, a Organização Internacional do Trabalho (OIT) realizou reunião em Genebra para tratar do problema da proteção da vida privada dos trabalhadores, debatendo diretivas práticas, que tinham como objetivo "fornecer orientações sobre proteção de dados pessoais dos trabalhadores". Esse documento, reconhecendo que a evolução das tecnologias não era incompatível com os direitos dos trabalhadores, salientou a necessidade de ser assegurado um equilíbrio entre o direito à privacidade dos trabalhadores e a imprescindibilidade de os empregadores obterem informações sobre os trabalhadores e a atividade por eles desenvolvida. Constatou-se, por outro lado, que a coleta substancial de informação sem o conhecimento dos trabalhadores produz efeitos nefastos sobre o direito à proteção da vida privada (GUERRA, 2004, p. 299-301).

Entre as diretivas práticas adotadas pela OIT, podem ser salientadas as seguintes:

- Os dados pessoais devem ser tratados de forma lícita e leal e, exclusivamente, por razões diretamente ligadas ao emprego do trabalhador (ponto $5.1)$

- Os dados pessoais obtidos através de meios técnicos que visam garantir a segurança e o bom funcionamento dos sistemas de informação automatizados não devem ser utilizados para controlar o comportamento dos trabalhadores (ponto 5.4);

- Os dados colhidos com recurso a sistemas de vigilância eletrônica não devem ser o elemento exclusivo de avaliação dos resultados e do rendimento do trabalhador (ponto 5.6);

- Os empregadores ou os seus representantes devem assegurar toda a informação em relação aos mecanismos de recolha de dados, regras por que se regem e direitos dos trabalhadores (ponto 5.8);

- Os empregadores, os trabalhadores e os seus representantes devem cooperar na proteção de dados pessoais e na elaboração de medidas relativas à proteção da vida privada dos trabalhadores, em conformidade com os princípios constantes das presentes diretivas (ponto 5.11);

- Os trabalhadores não podem renunciar aos seus direitos relativos à proteção da sua vida privada (ponto 5.13);

- Devem ser do conhecimento prévio dos trabalhadores a existência de sistemas de vigilância, as razões que determinaram sua adoção, os respectivos períodos, os métodos e técnicas utilizadas, bem como os dados obtidos.

- O empregador deverá reduzir a ingerência na vida privada dos trabalhadores. Toda "vigilância secreta" não deverá ser autorizada, salvo se: a) estiver prevista e conforme com a legislação nacional e b) existirem suspeitas, 
razoavelmente justificadas, de atividades criminais ou outras infrações graves. Toda "vigilância permanente" não deverá ser autorizada a não ser por razões de saúde e de segurança ou com o objetivo de proteger os bens da empresa (ponto 6.14).

Na União Europeia, o Grupo de Trabalho do artigo $29,{ }^{3}$ depois de analisar a jurisprudência respeitante ao artigo $8^{\circ}$ da Convenção para a Proteção dos Direitos do Homem e das Liberdades Fundamentais, evidenciou três princípios básicos:

a) Os trabalhadores têm uma expectativa legítima de privacidade no local de trabalho, a qual não é sobreposta pelo fato de os trabalhadores usarem material de comunicações ou quaisquer outras infraestruturas comerciais do empregador;

b) O princípio geral da confidencialidade da correspondência abrange as comunicações no local de trabalho, sendo provável que estas comunicações incluam o correio eletrônico, os fichários com eles relacionados e anexos às comunicações;

c) O respeito pela vida privada inclui igualmente, até um certo nível, o direito de estabelecer e desenvolver relações com outros seres humanos.

Em relação à Carta dos Direitos Fundamentais da União Europeia, entendeu o Grupo que foi alargado o conceito de confidencialidade da correspondência para se tornar um conceito de nova geração - "confidencialidade das comunicações"que se destina a facultar às eletrônicas o mesmo grau de proteção que o correio tem recebido tradicionalmente.

No plano interno, a privacidade, na Constituição brasileira de 1988, foi tratada no seu artigo $5^{\circ}, \mathrm{X}$, e declarou invioláveis a intimidade, a vida privada, a honra e a imagem das pessoas. Ademais, o legislador também abrigou de forma expressa a proteção a outros direitos reflexos dos direitos à intimidade e à vida privada. Assim, nos incisos 11 e 12 do indigitado artigo, declarou inviolável o domicílio, o sigilo das comunicações e das correspondências.

Analisadas tais disposições constitucionais, é possível destacar que há menção tanto à intimidade quanto à vida privada; para este estudo, adotou-se o termo "privacidade", já que é tarefa complexa a distinção desses direitos. De qualquer sorte, oportuno referir que a garantia do direito à vida privada já englobaria a intimidade ou, por exemplo, também a inviolabilidade da correspondência. No entanto, a definição constitucional, ao declarar tais direitos de forma apartada, como direitos autônomos, pretendeu conceder segurança detalhada a fim de não permitir interpretações restritivas, talvez em resposta ao longo período autoritário antecedente à Carta de 1988, quando não se observava a proteção desses direitos (ARAUJO, 2002, p. 102-103).

A proteção constitucional da vida privada, conforme Moraes (2005, p. 124125), é formada pelos direitos à intimidade e à vida privada. Segundo o autor, os

\footnotetext{
3 Grupo consultivo independente composto por representantes das autoridades responsáveis pela proteção de dados dos Estados-Membros, cuja tarefa é examinar todas as questões relacionadas com a aplicação das medidas nacionais adotadas em conformidade com a Diretiva sobre proteção de dados, de forma a contribuir para a uniformidade dessa mesma aplicação (GUERRA, 2004. p. 302).
} 
conceitos de intimidade e vida privada se inter-relacionam, mas são diferenciados pelo fato de que o primeiro apresenta menor amplitude, encontrando-se no âmbito de incidência do segundo. Assim, o conceito de intimidade se direcionaria às relações subjetivas e de trato íntimo do ser humano, envolvendo família e amizades, por exemplo, enquanto a definição de vida privada envolveria todos os relacionamentos do homem, inclusive os objetivos, como relações de trabalho e de estudo.

Importante contribuição na investigação da privacidade, da intimidade e da vida privada é determinada pela doutrina alemã, ao conceber que a primeira comporta divisões em círculos concêntricos. À medida que o conteúdo dos fatos se torna mais íntimo, tem-se uma esfera da privacidade que permite menor grau de interferência. Assim, a vida privada compreenderia a esfera maior, na qual se localizam os fatos que o indivíduo não deseja que se tornem públicos, ou seja, aqueles acontecimentos que não estariam ao alcance da coletividade em geral, a exemplo de comportamentos que somente devem ser conhecidos por aqueles que convivem regularmente com a pessoa. Dentro desse círculo estaria a esfera íntima ou confidencial na qual se encontram os fatos do conhecimento das pessoas que gozam da confiança do indivíduo. São as circunstâncias da sua vida que somente são compartilhadas com familiares, amigos e colaboradores. No centro está a esfera do secreto, especialmente protegida, em que se guardam os segredos revelados a poucas pessoas ou a ninguém, compreendendo assuntos extremamente reservados, como a vida sexual, por exemplo. Tal distinção possui um importante caráter prático, uma vez que quanto menor a esfera, maior o nível de proteção (SILVEIRA NETO; PAIVA, 2003).

Há doutrinadores, como Silva (2006, p. 206), que não concebem os direitos à vida privada e à intimidade de forma autônoma, adotando terminologia genérica, de modo a abarcar todas as manifestações da esfera íntima e privada que a Carta Magna buscou consagrar. Assim, na concepção do autor, privacidade seria o conjunto de informações acerca do indivíduo que ele pode decidir manter sob seu exclusivo controle, ou comunicar, decidindo a quem, quando, onde e em que condições, sem isso poder ser legalmente sujeito.

Efetivamente, tanto a vida privada quanto a intimidade podem ser vistas, em sentido amplo, como o direito ao resguardo, visto que englobam fatos particulares do indivíduo que não merecem ser tornados públicos. Portanto, as circunstâncias que compreendem os dois acontecimentos, em tese, englobariam a proteção do mesmo bem jurídico: o recato (ou resguardo). Todavia, conforme já mencionado, a Carta Magna atual, em que pese conceder o mesmo grau de importância jurídica, tratou referido bem de forma apartada, pois declarou inviolável a intimidade e a vida privada. Ambos os conceitos apresentam grande interligação, porém, diferenciam-se por ser o primeiro menos amplo que o segundo, encontrando-se, assim, no âmbito de incidência deste. Dessa maneira, pode-se afirmar que a "intimidade" envolveria fatos mais particulares da pessoa, inserindo-se no gênero "vida privada", que compreenderia todos os fatos que o indivíduo não deseja tornar público. 
A intimidade diz respeito às relações subjetivas e de trato íntimo da pessoa, suas relações familiares e de amizade; a vida privada envolve um campo maior, englobando os demais relacionamentos humanos, inclusive as relações comerciais, de trabalho, de estudo, entre outros.

Nesse prisma, a Constituição brasileira, ao prever a intimidade, a vida privada, a honra, o sigilo da correspondência e das comunicações, como direitos e garantias fundamentais, pretendeu alcançar a esses a posição máxima no ordenamento jurídico. Assim o fazendo, o legislador estabeleceu formalmente uma prestação positiva e negativa do Estado: negativa ao garantir a não intervenção na esfera privada do indivíduo, isto é, uma abstenção do Estado; positiva no sentido de exigir uma efetiva prestação estatal. Além disso, por ser norma máxima na ordem jurídica, em tese, tais direitos não estariam sujeitos à modificação, ou, na pior hipótese, seriam submetidos a um processo de alteração mais complexo, nos termos do artigo $60, \S 4^{\circ}, \mathrm{IV}$, da CF.

Diante de tais assertivas, constata-se que a vida privada e a intimidade são direitos individuais considerados de primeira geração, pois se relacionam à liberdade, ou seja, sua natureza jurídica é de direito fundamental (BARROS, 1997, p. 32). São direitos da personalidade inerentes ao indivíduo, que jamais desaparecem no tempo e que não se separam do seu titular. Por essa razão, são direitos existentes em qualquer relação jurídica, portanto, à relação de emprego também aplicáveis. Cumpre referir que, no entanto, assim como os demais direitos da personalidade, não são ilimitados. Apesar de oponíveis contra todos, exigindo um dever geral de abstenção, podem sofrer limitação, consoante adiante será tratado, quando em conflito com outros direitos fundamentais ou em benefício do interesse público, como para garantir a segurança nacional ou para viabilizar a atividade investigatória do Estado, ${ }^{4}$ por exemplo, quando ocorre autorização judicial para a quebra do sigilo bancário ou escuta telefônica.

Coadunando-se aos preceitos constitucionais e configurando uma mudança de paradigma, ${ }^{5}$ à medida que abandonada a visão meramente patrimonialista do Código Civil de 1916, ainda que comporte algumas críticas, ${ }^{6}$ o artigo 21 do Código Civil Brasileiro de 2002 disciplinou, expressamente, a proteção à vida privada: Art. 21. "A vida privada da pessoa natural é inviolável, e o juiz, a requerimento do interessado, adotará as providências necessárias para impedir ou fazer cessar ato contrário a esta norma.

\footnotetext{
4 O próprio Código Civil Brasileiro, no artigo 20, limita os direitos da personalidade enumerados nesse dispositivo quando autorizados ou se necessário à administração da justiça ou à manutenção da ordem pública.

5 Tal mudança pode ser bem justificada nas palavras de Fachini Neto (2006, p. 41), quando afirma que a Constituição não é apenas um programa político a ser desenvolvido pelo legislador e pela administração, mas contém normatividade jurídica reforçada, pois suas normas são qualitativamente distintas e superiores às outras normas do ordenamento jurídico, uma vez que incorporam os sistemas de valores essenciais à convivência social, devendo servir como parâmetro para todo o ordenamento jurídico, além de auxiliar a este como critério informativo e validante. 6 Uma das críticas formuladas ao capítulo dos Direitos da Personalidade ao novo Código Civil é a de que não foi disciplinada, expressamente, uma cláusula geral relativa ao livre desenvolvimento da personalidade, o que facilitaria a aplicação prática, na atividade jurisprudencial, quando da descoberta de novos aspectos da personalidade humana que, sendo lesados ou estando sob a ameaça de lesão, merecem tutela adequada, ainda que não tipificados em texto legislativo (MARTINS-COSTA, 2006, p. 80).
} 
A questão que se coloca, então, considerando-se a dimensão e a importância do direito à privacidade no ordenamento jurídico brasileiro, e que se abordará a seguir, é tratar da sua compatibilização quando diante da relação de emprego. Nesse sentido, entende-se fundamental analisar o poder diretivo do empregador e suas eventuais limitações, a fim de que, posteriormente, possam ser examinados os eventuais conflitos e suas possíveis soluções envolvendo a privacidade do empregado no contrato de trabalho.

\section{Poder de direção do empregador e suas limitações}

A palavra poder, etimologicamente, está vinculada à ideia de chefia, consiste em fazer os outros agirem da forma pretendida pelo emissor da vontade. Para que ocorra a aceitação desse poder e a concretização da ordem, será necessária a aceitação do comando, ou seja, o poder emanado por uma pessoa vincula-se à sujeição e à obediência de outra. Transferindo-se para a relação de emprego, esse "poder" recai sobre a figura do empregador, na medida em que é o proprietário dos meios de produção; porquanto é a autoridade na empresa; porquanto pactuou em um contrato; porquanto controla juridicamente o conjunto da estrutura empresarial; porquanto assumiu os riscos da atividade empresarial (COUTINHO, 1999, p. 13-14).

A definição de poder diretivo não é abordada especificamente pela legislação brasileira, diferentemente, por exemplo, do Código do Trabalho de Portugal, aprovado pela Lei n. 99/2003, que, no artigo 150, reconhece expressamente a existência de um poder diretivo ao dispor que ao empregador cumpre a fixação dos termos em que o trabalho deve ser prestado: "Artigo 150. Poder de direcção. Compete ao empregador, dentro dos limites decorrentes do contrato e das normas que o regem, fixar os termos em que deve ser prestado o trabalho."

$\mathrm{Na}$ Consolidação das Leis do Trabalho apenas é encontrada uma referência de quem dirige a relação de emprego a partir do artigo $2^{\circ}$, quando considera empregador aquele que "[...] dirige a prestação de serviços." P Porém, ainda que a legislação

\footnotetext{
Existem três teorias que procuram justificar a natureza jurídica do poder de direção: a teoria da propriedade, a teoria do contrato e a teoria institucional. Para a teoria da propriedade (adotada por Mozart Victor Russomano, Evaristo de Moraes Filho, José Marthins Catharino), o poder de direção ocorre em razão do direito de propriedade do empregador, ou seja, por ser esse o detentor dos fatores de produção e, assim, o responsável pelos riscos da atividade econômica. A Teoria Contratualista (adotada por Délio Maranhão, Arion Sayão Romita) justifica o poder diretivo na própria relação de emprego. Segundo esta, seria o contrato de trabalho o precursor do poder de direção, na medida em que por meio do acordo de vontade entre as partes nasce a obrigação do empregado de prestar serviços, formando-se, assim, a sujeição deste ao comando do empregador, disso advindo à subordinação jurídica da relação de emprego. A teoria institucional (que teve como precursores Maurice Hauriou e Georges Renard, sendo seguida por Mesquita, apud Gonçalves (1997, p. 20-21) destaca o fato de o obreiro estar inserido na empresa-instituição, devendo obedecer às suas regras e colaborar conjuntamente com o empregador na busca do fim empresarial. Todas as três teorias sofrem críticas pela doutrina, não havendo unanimidade em relação a qual realmente seria a justificadora do poder diretivo. A teoria contratualista é contestada sob o argumento de que reconhece o poder diretivo apenas pelo seu aspecto formal. A teoria da instituição não seria adequada pelo fato de apenas justificar determinada situação de poder, sem explicá-la. A teoria da propriedade porque nos dias atuais cada vez mais se distanciam os proprietários da empresa, os quais muitas vezes nem mesmo são conhecidos, como ocorre nas sociedades por ações. Nesse sentido, em virtude da delimitação do presente estudo, não será adotada esta ou aquela teoria, uma vez que as três
} 
brasileira não conceitue expressamente o poder diretivo aos moldes do Código do Trabalho português, não se discute a existência de uma direção na relação de emprego que caracteriza o empregador. A título exemplificativo, o ordenamento jurídico brasileiro atribui ao empregador o dever de realizar determinados atos de fiscalização, como, por exemplo, a necessidade de manter controle sobre a jornada de trabalho dos empregados, consoante o artigo 74, $\S 2^{\circ}$, da Consolidação das Leis do Trabalho. ${ }^{8}$

$\mathrm{Na}$ concepção de Vilhena (1999, p. 210), ${ }^{9}$ a direção que qualifica a pessoa como empregador é um poder-função atrelado a um campo certo de misteres, que tem por objeto o cumprimento de determinados fins, de natureza técnica. Referido autor leciona que, ao conceber-se a empresa como unidade técnico-econômica de produção ou troca de bens e serviços, duas ordens básicas de consideração devem ser expostas: externamente, a empresa realiza fins; internamente, organiza-se e opera. Para que se alcance a finalidade empresarial, tornam-se indispensáveis a coordenação e a harmonização entre as atividades desenvolvidas pela empresa. Dessa forma, considerando que a assunção de riscos da atividade econômica recai tão somente sobre o empregador, é este quem deverá imprimir os rumos do negócio e conduzir a atividade laboral.

O poder de direção pode ser visto como a forma pela qual o empregador define como será desenvolvida a obrigação do empregado decorrente do contrato de trabalho. Compreende não apenas o poder de organizar as atividades, mas também o de controlar e disciplinar o trabalho, de acordo com os fins do empreendimento, o que demonstra que o empregador possui diversas prerrogativas na condução do seu negócio, ou seja, que o poder diretivo se desmembra por várias facetas. Camino (2004, p. 229) leciona que as múltiplas formas de expressão do poder diretivo podem ser sintetizadas nos atos de regulamentar a relação de emprego, distribuir, dirigir, orientar e fiscalizar, adequar a prestação às necessidades da empresa e impor sanções disciplinares ao empregado faltoso.

Vincula-se o poder diretivo às normas constitucionais que consagram os valores sociais da livre-iniciativa como princípio fundante da República, nos termos do artigo $1^{\circ}$, IV e o princípio geral da atividade econômica, cujo livre exercício a todos é assegurado, nos termos do artigo 170, II e parágrafo único (LEWICK, 2003, p. 190). Além disso, a Constituição Federal de 1988, no artigo $5^{\circ}$, XXII, garantiu o direito de propriedade. Assim, todos os meios de produção pertencentes ao empregador e que

correntes oferecem elementos que servem como fonte do poder de direção. Portanto, seria mais adequada uma espécie de teoria eclética, já que incontestavelmente o aludido poder se justifica no contrato, na própria necessidade de se alcançar o fim da empresa e na propriedade daquele que detém o capital e o trabalho (SIMÓN, 2000, p. 110).

8 Art. $74[\ldots] \S 2^{\circ}$ Para os estabelecimentos de mais de dez trabalhadores será obrigatória a anotação da hora da entrada e da saída, em registro manual, mecânico ou eletrônico, conforme instruções a serem expedidas pelo Ministério do Trabalho, devendo haver pré-assinalação do período de repouso.

9 Aduz, ainda, que o sistema organizativo da empresa pressupõe uma escala hierárquica em forma triangular. Na base, estão o operário, o trabalhador comum, os manipuladores, os tidos por operacionais, os incumbidos da execução direta (seja mais ou menos intelectual o trabalho) e no ápice, o empregador ou quem lhe faça às vezes (VILHENA, 1999, p. 211). 
se materializam na empresa, no estabelecimento, no imóvel onde se localiza o estabelecimento, nos bens que compõem esse estabelecimento, no modo de produção, nas invenções, nas estratégias de atuação no mercado, no produto, etc. integram o objeto do seu direito de propriedade, sendo passíveis de proteção constitucional, determinada pelo artigo citado (SIMÓN, 2000, p. 116). Portanto, não se pode negar que, sendo o empregador titular do empreendimento, protegido pelo direito de propriedade, possui a faculdade de coordenar os rumos da atividade econômica.

Em síntese, o poder diretivo estende-se a todos aqueles atos de previsão que, sobre o trabalho de outrem, impliquem garantia dos meios de manter-se a regular atividade do processo produtivo ou de troca de bens e serviços, compreendendo a disponibilidade dos meios de produção neste, incluindo-se a atividade do empregado (VILHENA, 1999, p. 215). Todas as formas de manifestação do poder patronal, todavia, dependerão da concretização da ordem e da aceitação do comando, isto é, o poder emanado pelo empregador vincula-se à sujeição e à obediência pelo empregado. Logo, o poder de direção está intimamente vinculado a uma característica fundamental do contrato de trabalho, qual seja, a subordinação do empregado em relação ao empregador, pois, conforme sustenta Nascimento (2004, p. 620), na relação de emprego “[...] o poder diretivo é um lado e a subordinação é o outro lado da moeda."

Para Romita (1979, p. 73), a subordinação é “[...] o lado passivo do poder de comando do empregador, ou seja, a faculdade que lhe é reconhecida de determinar (por meio de comandos mais ou menos genéricos) o conteúdo das prestações de trabalho." Vilhena (1999, p. 473) conceitua subordinação como a participação integrativa da atividade do trabalhador na atividade do credor do trabalho.

É esclarecedora a definição de subordinação como uma situação em que se encontra o trabalhador, decorrente da limitação contratual da autonomia da sua vontade, para o fim de transferir ao empregador o poder de direção sobre a atividade que desempenhará. Todavia, a existência de subordinação na relação de emprego não autoriza o exercício do poder diretivo de forma absoluta, visto que este sofre limitações, embora não seja fácil identificar as suas fronteiras. A própria natureza da subordinação existente na relação de emprego, qual seja, subordinação jurídica, evidencia que o poder de direção do empregador não é absoluto. O ordenamento jurídico brasileiro não delimita expressamente até que ponto são permitidas as atividade de fiscalização e de controle empresarial. Porém, existem regras e princípios aptos a averiguar o exercício legítimo ou abusivo do poder de direção.

A limitação ao poder diretivo pode ser colocada em dois sentidos, conforme Gomes e Gottschalk (2005. p. 71):

a) pela lei, pelas fontes de produção profissional e pelo próprio contrato individual de trabalho;

b) pela finalidade do direito de direção. 
Por meio da primeira, o poder diretivo vincula-se às leis, às sentenças normativas e às normas coletivas, em síntese, não pode o empregador ordenar o empregado afrontando as prescrições sobre a regulamentação do trabalho em geral, ou às exigências de ordem pública ou dos bons costumes. Em relação ao segundo sentido, deve-se perceber que o poder diretivo somente tem razão de existência no intuito de conferir ao empregador a possibilidade de alcançar uma boa organização do trabalho na empresa, não se justificando por mero capricho deste.

Dessa forma, o estado de sujeição do empregado denota apenas a subordinação hierárquica decorrente do contrato de trabalho. No entanto, em que pese a existência dos devere ${ }^{10}$ de obediência, de diligência e de fidelidade do empregado, ${ }^{11}$ não significa que o empregador tenha a disponibilidade sobre a pessoa do trabalhador, pois, conforme Vilhena (1999, p. 213), não há poderes de homens sobre homens, mas sim relações jurídicas, na medida em que o que se sobrepõe às pessoas, seja pelo contrato seja pela instituição, é a lei.

Conforme anteriormente exposto, o objeto do contrato de trabalho é a prestação de serviços, importando, pois, a atividade como elemento vinculado à empresa, que nada mais é do que uma soma de atividades distribuídas em um processo organizado de desenvolvimento. Portanto, o que se objetiva é a regularidade, a continuidade e a segurança dessa atividade para a consecução dos fins intercalares e últimos da empresa. Este, para Vilhena (1999, p. 214-215), é o limite de exercício do poder diretivo que a ordem jurídica confere ao empresário.

A limitação do poder diretivo deve ser observada a partir da participação efetiva do trabalhador na atividade empresária, pois o reconhecimento desse poder pretende assegurar meios de regular o desenvolvimento da atividade empresarial. Portanto, sustenta Vilhena (1999, p. 216), o que se deve buscar nas relações de trabalho e em seu fundamento é a finalidade, o elemento básico, que torna admissível o exercício de certos poderes conferidos ao empregador. Sustenta, também, que esse elemento básico, a finalidade dos poderes (o de comando, o de organização, o de controle, o de previsão e o de coordenação) que exterioriza a imagem jurídica do empregador, resume-se na segurança, e não na confiança, do regular andamento de sua atividade. Em verdade, a segurança amplifica o espectro de irradiação dos poderes empresariais. É ela, porém, o suposto de realidade sobre o qual se assenta a empresa, como unidade de produção ou de troca de bens e serviços. O limite, portanto, desse poder diretivo, é a segurança

\footnotetext{
${ }_{10}$ O dever de obediência é inerente ao poder diretivo e a sua inobservância pelo empregado caracteriza as faltas por insubordinação ou indisciplina (artigo 482, "h" da CLT). No entanto, o contrato de trabalho gera direitos e obrigações não apenas de cunho patrimonial, mas também de caráter pessoal, em que se insere o aspecto ético, cujo dever de fidelidade é uma de suas manifestações. A violação a tal dever pelo empregado pode caracterizar as faltas como negociação habitual e violação de segredo (artigo 482, "c" e "g" da CLT). O dever de diligência impõe que o empregado realize suas obrigações com zelo, podendo, em caso de inobservância, ensejar sanção disciplinar por desídia (art. 482, "e" da CLT). Sobre os deveres do empregado, vide Barros (2005, p. 578).

11 A legislação trabalhista não define expressamente quais são os deveres do empregado, o que, todavia, não importa afirmar que a CLT é omissa em relação ao assunto, uma vez que tais deveres são extraídos a partir do artigo 482 da CLT quando arrola as faltas ensejadoras de justa causa.
} 
na regular marcha da atividade empresária. É o que se considera limite técnico e que, em geral, coincide com sua outra face, o limite jurídico (VILHENA, 1999, p. 216).

Asseverando que a natureza jurídica do poder diretivo se trata de um direito-função, na medida em que o artigo 421 do Código Civil ${ }^{12}$ consagra a função social do contrato, Barros sustenta que o poder diretivo possui limites externos, impostos pela Constituição, por outras leis, pelo contrato e pelas normas coletivas, e também um limite interno, que impõe o exercício do poder em conformidade com a boa-fé. Com base nesses limites, a autora sustenta que é legítimo ao empregado recusar ordens emitidas por quem não está legitimado a fazê-lo, ordens ilícitas ou capazes de lesar direitos à sua integridade física ou moral.

Analisando-se sobre outro prisma, a limitação do poder diretivo poderia ser também explicada a partir de um dos fundamentos do poder diretivo, ou seja, por meio do direito de propriedade do empregador, visto que este é o dono dos meios de produção; é quem assume o risco da atividade empresarial; é quem controla o complexo de bens que envolve a empresa; é o responsável pela estrutura jurídica do empreendimento; é quem determina a força de trabalho. O fundamento do poder no sistema capitalista é a propriedade privada e, assim, somente o órgão ou a pessoa que representa a propriedade majoritária do empreendimento pode exercê-lo como titular (COUTINHO, 1999, p. 117).

Também sob esse aspecto e da mesma forma que os demais direitos fundamentais, o direito de propriedade também sofre limitações. O próprio inciso XXIII, do artigo $5^{\circ}$, da Constituição Federal, determina que a propriedade deve atender à sua função social. Além disso, a Carta Magna vincula a propriedade e sua função social com princípios da atividade econômica, disciplinando que, no artigo 170, incisos II e III, in verbis: "A ordem econômica, fundada na valorização do trabalho humano e na livre iniciativa, tem por fim assegurar a todos existência digna, conforme os ditames da justiça social, observados os seguintes princípios: II - propriedade privada; III - função social da propriedade.” (BRASIL, 1988).

Outro fator que deve ser observado na limitação ao poder diretivo é que toda a relação jurídica, de emprego ou de qualquer outra natureza deve zelar pela dignidade da pessoa humana. Não foi por menor razão que o legislador, no que repisa ao direito do trabalho, por meio do artigo 170, caput, da Carta Magna, relacionou a vida digna ao princípio da valorização do trabalho humano. Isso porque a dignidade humana não é apenas o fundamento do Estado Democrático de Direito, mas de todas as relações jurídicas e humanas. Por essa razão, o poder de direção jamais pode ser utilizado para a obtenção de vantagens indevidas e em desrespeito aos direitos fundamentais.

Conclui-se, assim, que a direção empresarial será limitada pelo próprio princípio da dignidade da pessoa humana, pelos diretos da personalidade do empre-

12 Artigo 421. A liberdade de contratar será exercida em razão e nos limites da função social do contrato (BRASIL, 2002). 
gado, ainda que no ambiente de trabalho, pois estes são indissociáveis da pessoa do trabalhador. Tal conclusão, ainda que não definitiva, naturalmente, comporta controvérsias em situações consideradas "cinzentas" em que se verifica uma colisão de direitos e conflitos de interesses entre empregado e empregador.

Desse modo, na próxima seção, serão examinadas algumas situações de conflitos decorrentes do confronto entre o poder diretivo do empregador e o direito à privacidade do empregado.

\section{Dos conflitos envolvendo a privacidade do empregado no contrato de trabalho}

Convém destacar, inicialmente, que, embora o escopo deste estudo, em razão da necessidade de delimitação do tema, seja a análise de conflitos envolvendo a privacidade do empregado diante dos procedimentos patronais de: revistas nos trabalhadores, fiscalização do ambiente de trabalho por meio de câmeras e monitoramento de e-mails; isto é, situações que ocorrem no curso do contrato de emprego, não se pode olvidar que nas fases pré ${ }^{13}$ e pós-contratual ${ }^{14}$ também é comum a ocorrência de litígios abrangendo o direito à privacidade do empregado. Com efeito, a relação de emprego está sujeita à ocorrência de conflitos dessa natureza, uma vez que envolve interesses por vezes antagônicos, quais sejam, a privacidade do empregado e o poder diretivo do empregador.

Dessa maneira, serão analisadas, a seguir, as três situações anteriormente elencadas, para, ao final, em sede de considerações finais, apresentarem-se algumas conclusões na solução desses conflitos.

\subsection{Da realização de revistas em trabalhadores}

O tema das revistas em empregados tem sido bastante discutido no âmbito da Justiça do Trabalho, uma vez que nem sempre se consegue conciliar o legítimo direito patronal de fiscalização, decorrente da defesa do direito de propriedade, garantido pelo artigo $5^{\circ}$, XXII, da $\mathrm{CF}$, com a privacidade do trabalhador, prevista no inciso X do mesmo artigo. No ordenamento jurídico brasileiro, a regulamentação

\footnotetext{
13 Exemplificativamente, pode-se citar, no momento que antecede a celebração do contrato de trabalho, a adoção de práticas discriminatórias no processo de seleção, quando se exigem informações de foro íntimo do candidato, expressamente vedadas pela CLT, conforme o artigo 373-A da CLT, que disciplina que é vedado publicar ou fazer publicar anúncio de emprego no qual haja referência ao sexo, à idade, à cor ou situação familiar, salvo quando a natureza da atividade a ser exercida, pública e notoriamente, assim exigir.

No mesmo sentido, disciplina a Lei n. 9.029/95: Artigo $1^{\circ}$ - Fica proibida a adoção de qualquer prática discriminatória e limitativa para efeito de acesso à relação de emprego, ou sua manutenção, por motivo de sexo, origem, raça, cor, estado civil, situação familiar ou idade, ressalvadas, neste caso, as hipóteses de proteção ao menor previstas no inciso XXXIII do artigo $7^{\circ}$ da Constituição Federal.

14 Na fase pós-contratual tem-se constatado a existência das chamadas "listas negras", que circulam no meio empresarial, relacionando empregados que ajuizaram reclamações trabalhistas contra suas ex-empregadoras, bem como a divulgação de informações desabonadoras do ex-empregado.
} 
da matéria é bastante sintética, ${ }^{15}$ na medida em que apenas se encontra previsão no artigo 373-A, VI da CLT, no capítulo destinado à proteção do trabalho da mulher, que veda a realização de revistas íntimas nas empregadas:

Art. 373-A. Ressalvadas as disposições legais destinadas a corrigir as distorções que afetam o acesso da mulher ao mercado de trabalho e certas especificidades estabelecidas nos acordos trabalhistas, é vedado: VI - proceder o empregador ou preposto a revistas íntimas nas empregadas ou funcionárias.

Veja-se que, ainda que se trate de norma específica de proteção ao trabalho da mulher, em razão do Princípio da Igualdade (artigo 5, I CF), não teria sentido deixar de aplicar essa proteção também ao empregado do sexo masculino, razão pela qual é patente que a norma se aplica independentemente de gênero. Além disso, outro fator que gera controvérsia se refere ao subjetivismo do conceito "íntimo", ou seja, no que consistiria a prática definida como "revistas íntimas"? Compreenderia apenas as formas de vistoria no próprio corpo do empregado, ou também nos seus pertences, como bolsas, sacolas e armários que utiliza na empresa?

Na Espanha, por exemplo, o artigo 18 do Estatuto do Trabalhador, estabelece que: "Só poderão ser feitas revistas sobre a pessoa do trabalhador, em seus armários e pertences, quando sejam necessárias para a proteção do patrimônio empresarial e dos demais trabalhadores da empresa, dentro do centro de trabalho e durante o horário de trabalho."

Tal dispositivo é muito criticado pela doutrina espanhola (José Manuel Del Valle Villar, Carlos Ruiz Miguel, entre outros), conforme exposto por Barros (1997), visto que consagraria a proteção do patrimônio em detrimento do direito à intimidade do empregado.

Na Itália, há previsão legal para a revista do empregado, dentro de certos limites, sendo, de acordo com o artigo $6^{\circ}$ do Estatuto do Trabalhador, autorizada a revista quando: "[...] indispensável para a tutela do patrimônio, somente podendo ser efetuada na saída dos locais de trabalho, através de um sistema de seleção automática, e resultante de acordo entre empregador e a representação dos trabalhadores."

No âmbito interno, diante da subjetividade do termo "revista íntima", a jurisprudência tem se encarregado de traçar algumas diretrizes para configurar a abusividade ou não desse procedimento pela empresa. Em entrevista concedida pelo então Corregedor Geral da Justiça do Trabalho, Ministro Barros Levenhagen, foi manifestado entendimento de que o poder diretivo do empregador permite a rea-

\footnotetext{
15 No estado do RS, pode-se citar a Lei n. 12.258, de 22 de abril de 2005, que dispõe sobre a prática de revistas íntimas nos funcionários pelas empresas, que proíbe, em todos os estabelecimentos industriais, comerciais e de serviços, a prática de revista íntima nos funcionários, entendendo-se como tal o despimento coercitivo, bem como todo e qualquer ato de molestamento físico que exponha o corpo dos funcionários. Cumpre referir que tal Lei foi objeto de Ação Direta de Inconstitucionalidade (ADI 3.559), com base na suposta violação ao artigo 22, inciso I, da Constituição Federal, que trata da competência privativa da União para legislar sobre Direito do Trabalho.
} 
lização de revistas, porém, desde que de forma moderada e observando inviolabilidade da privacidade do empregado. Foi exposto pelo Ministro que "[...] a revista realizada com moderação e razoabilidade não caracteriza abuso de direito ou ato ilícito, constituindo, na realidade exercício regular do direito do empregador ao seu poder diretivo de fiscalização," (CORTES, 2013), exemplificando que a revista em bolsas, sacolas ou mochilas não denuncia excesso do empregador e raramente gera indenização por dano moral, “[...] desde que não se proceda à revista íntima e sem contato corporal, mas apenas visual do vistoriador, e em caráter geral, relativamente aos empregados do mesmo nível hierárquico." (CORTES, 2013). Contudo, o Ministro ponderou que "[...] o empregador no uso do poder diretivo que lhe confere o artigo $2^{\circ}$ da CLT não pode se exceder nesses atos de coordenação e fiscalização do trabalho. Daí porque quando atinge o valor imaterial da privacidade, submetendo o empregado a uma revista vexatória, incorre em dano moral e até imaterial." (CORTES, 2013).

Com efeito, a jurisprudência tem entendido que, em regra, as revistas realizadas em empregados, por si só, não são suficientes para ensejar o pagamento de danos morais, o que apenas ocorreria, contudo, quando caracterizada a ação abusiva por parte da empresa. Na decisão a seguir, por exemplo, demonstra-se que, mesmo sendo a revista meramente visual nos pertences dos empregados, por ser realizada na frente de clientes da reclamada, já que efetivada na portaria da empresa, local pelo qual a clientela ingressava e saía do estabelecimento empresarial, tal prática foi entendida como abuso do poder de fiscalização do empregador, visto que causaria constrangimento aos empregados. Disso, conclui-se, a contrário senso, que seria admitida a revista caso feita em local discreto e longe dos olhos do público em geral:

DANOS MORAIS. COBRANÇAS. REVISTA DE EMPREGADOS. As revistas realizadas, estas, por si só, não são suficientes para ensejar o pagamento de danos morais ao empregado, o que ocorre somente quando evidenciada a ação abusiva por parte da empresa. Entretanto, restou comprovado que as revistas dos empregados eram realizadas na frente de clientes, pois realizada na portaria, local pelo qual os clientes entram e saem da empresa, sendo inequívoco que tal prática excede o poder de fiscalização do empregador, causando constrangimento à obreira, que se vê diariamente obrigada a comprovar sua inocência na frente de terceiros. A realização das revistas seria admissível se feita em local discreto e longe dos olhos do público em geral. Da maneira em que realizadas, entende-se que as revistas feriram a dignidade da trabalhadora, causando-lhe constrangimentos que transcendem os simples dissabores, tratando-se de ato inadmissível, que não pode ser chancelado pelo Poder Judiciário. Neste caso, é devida a reparação dos danos extrapatrimoniais causados, não cabendo a exclusão da condenação, na forma pretendida pela empresa. (RIO GRANDE DO SUL, 2013).

Já na decisão a seguir, a abusividade da revista estaria caracterizada, segundo o julgado do TRT da $4^{\text {a }}$ Região, pela existência de revista manual com o toque nos corpos dos empregados, conforme Acórdão de lavra do Desembargador José Felipe Ledur: 
A apalpação de empregado ou mesmo ordem no sentido de que retire suas vestes para efeito de resguardar a propriedade do empregador são medidas que não atendem aos elementos adequação e necessidade presentes no princípio da proporcionalidade. O fato de o reclamante realizar a revista manual em alguns empregados não afasta o constrangimento sofrido com a revista manual realizada pelos seus superiores. Assim, tem-se por ocorrida situação geradora de dano moral, o qual deve ser indenizado pela reclamada. (RIO GRANDE DO SUL, 2012a).

No mesmo sentido é a decisão seguinte, que classificou o procedimento de revista como vexatório e constrangedor, na medida em que os empregados ficavam expostos, tendo seus corpos apalpados quando do término da jornada ao saírem da empresa, conforme ementa a seguir:

INDENIZAÇÃO POR DANOS MORAIS. REVISTA ÍNTIMA. A indenização por dano moral está prevista no artigo $5^{\circ}$, incisos V ("é assegurado o direito de resposta, proporcional ao agravo, além da indenização por dano material, moral ou à imagem") e X ("são invioláveis a intimidade, a vida privada, a honra e a imagem das pessoas, assegurado o direito à indenização pelo dano material ou moral decorrente de sua violação") da CF. No caso dos autos, a prova oral demonstrou que as revistas eram realizadas de maneira vexatória, gerando constrangimentos e humilhações perante os demais, pois os empregados ficavam expostos tendo seus corpos apalpados quando da saída da empresa. Portanto, restando comprovado que o reclamante teve sua intimidade e honra violados, faz jus ao pagamento de indenização por danos morais. (RIO GRANDE DO SUL, 2012b).

Dos arestos analisados, portanto, constata-se que a jurisprudência tem caracterizado a revista íntima como aquela que envolve contato direto com o corpo dos empregados. Ao contrário disso, alguns julgados têm entendido, dessa forma, que a revista realizada para coibir furtos de mercadorias, por funcionário do mesmo sexo, com o uso de uma raquete eletrônica com detector de metal, em que nenhum empregado é apalpado, não evidencia conduta abusiva ou discriminatória pelo empregador. Nos termos da decisão a seguir, por exemplo, a maneira como é realizada a revista é que definirá a ocorrência ou não de dano moral. Nos termos da fundamentação do acórdão transcrito, a revista rotineira dos empregados e das suas bolsas e sacolas constitui procedimento legítimo do empregador, como meio de proteção de seu patrimônio, conforme:

INDENIZAÇÃO POR DANOS MORAIS. REVISTA. A revista rotineira dos empregados e das suas bolsas e sacolas constitui procedimento legítimo do empregador, como meio de proteção de seu patrimônio. A maneira como é realizada a revista é que definirá a ocorrência ou não de dano moral, o que, no caso, não restou configurado, uma vez que não evidenciada conduta ilícita ou abusiva por parte da reclamada. (RIO GRANDE DO SUL, 2014).

Dessa maneira, os tribunais trabalhistas, em regra, entendem que é legítimo ao empregador, em razão do seu poder diretivo e na busca da preservação de seu patrimônio, realizar o procedimento revista, quando indistintamente em todos os empre- 
gados, consistindo em mera visualização do conteúdo de bolsas e sacolas, sem contato com esse conteúdo e sem contato físico com o empregado, conforme decisão a seguir:

REVISTA. DANO MORAL. A reclamada, diante de seu poder diretivo e na busca da preservação de seu patrimônio, pode realizar os atos necessários a tal fim, observados os limites que decorrem do ordenamento jurídico. $\mathrm{Na}$ hipótese, não se verifica ter havido violação à honra, imagem, dignidade, intimidade ou privacidade da reclamante e tampouco ter a reclamada agido de forma discriminatória. Revista realizada indistintamente em todos os empregados, consistindo em mera visualização do conteúdo de bolsas e sacolas, sem contato com esse conteúdo e sem contato físico com o empregado. Dano moral não caracterizado. Provimento negado [...] A reclamada, diante de seu poder diretivo e na busca da preservação de seu patrimônio, pode realizar os atos necessários a tal fim, observados os limites que decorrem do ordenamento jurídico. Na hipótese, não se verifica ter havido violação à honra, imagem, dignidade, intimidade ou privacidade da reclamante e tampouco ter a reclamada agido de forma discriminatória. A atuação da ré pautada por limites legais inviabiliza o acolhimento do pleito da reclamante. $\mathrm{O}$ fato de esta, segundo alega no apelo, ter sempre sido contrária à revista nas bolsas e sacolas não se traduz em direito à indenização postulada, que pressupõe a ocorrência de ato ilícito causador de dano, inexistentes no caso. Nega-se provimento. (RIO GRANDE DO SUL, 2007).

Por outro lado, cumpre frisar que há também entendimento divergente, ainda que minoritário, quanto ao julgado anterior, conforme, por exemplo, demonstrado no Enunciado n. 15 da Escola Nacional de Formação e Aperfeiçoamento de Magistrados do Trabalho (Enamat), editado pela Comissão Científica da Sessão Plenária da $1^{\text {a }}$ Jornada de Direito Material e Processual na Justiça do Trabalho, realizada em conjunto com a Associação Nacional dos Magistrados do Trabalho e Tribunal Superior do Trabalho (Anamatra), com o apoio do Conselho Nacional das Escolas de Magistratura do Trabalho Conematra, em novembro de 2007:

Enunciado n. 15: REVISTA DE EMPREGADO.

I - REVISTA - ILICITUDE. Toda e qualquer revista, íntima ou não, promovida pelo empregador ou seus prepostos em seus empregados e/ou em seus pertences, é ilegal, por ofensa aos direitos fundamentais da dignidade e intimidade do trabalhador.

II - REVISTA ÍNTIMA - VEDAÇÃO A AMBOS OS SEXOS. A norma do art. 373-A, inc. VI, da CLT, que veda revistas íntimas nas empregadas, também se aplica aos homens em face da igualdade entre os sexos inscrita no art. $5^{\circ}$, inc. I, da Constituição da República.

Com a devida vênia ao enunciado anterior, entende- se que não seria ilegal “[...] toda e qualquer revista, íntima ou não, promovida pelo empregador ou seus prepostos em seus empregados e/ou em seus pertences"; pelo contrário, poderia ser considerada abusiva a revista pessoal, realizada diretamente no corpo do empregado, de cunho desproporcional, discriminatório e persecutório, sem que exista justificada necessidade de proteção do patrimônio do empregador, diante da existência de outros meios menos intrusivos (por exemplo, quando não houver a possibilidade da adoção de outras medidas preventivas, como etiquetas magnéticas, controle de 
entrada e saída de estoque) e, ainda, sem a prévia ciência pelos empregados, caracterizando-se como mero comodismo do empregador. Isso porque, nessas situações, o procedimento de fiscalização se apresentaria excessivo, caracterizando violação à privacidade do empregado, até mesmo porque, em razão do elo de fidúcia que une as partes no pacto laboral, há maior razão para se observar o princípio da boa-fé.

\subsection{0 uso de câmeras de vídeo como fiscalização no ambiente de trabalho}

A utilização de câmeras de vídeo é realidade frequente no meio empresarial, visto que é inegável o grave problema social da violência e da falta de segurança originado pela ineficiência do Estado. Ao mesmo tempo, não se verifica uma legislação específica em relação aos limites da videovigilância, principalmente, no ambiente de trabalho. Assim, a exemplo do que já foi abordado anteriormente em relação às revistas, é comum a ocorrência de conflito entre a privacidade do empregado diante do monitoramento por câmeras no local de trabalho e o poder diretivo do empregador, que também visa à preservação do seu patrimônio.

Barros (2005, p. 569) afirma que o legislador brasileiro não proibiu de forma expressa a fiscalização e o controle por meio de aparelhos audiovisuais, embora também não os tenha autorizado. $O$ fato é que o instrumento tem se legitimado por ser uma “[...] decorrência lógica do avanço da tecnologia e poderá consistir em um instrumento probatório valioso na avaliação da conduta do empregado."

Diferente do ordenamento jurídico brasileiro, no direito espanhol, por exemplo, conforme o artigo 20.3 do Estatuto do Trabalhador, ${ }^{16}$ tal procedimento será legítimo quando houver um interesse adequado, significativo e legítimo para a salvaguarda de bens e, ao contrário, será abusivo quando realizado em locais onde não se aproveite a informação obtida por meio da filmagem.

No âmbito do direito pátrio, para o Procurador do Trabalho Byruchko Junior (2006, p. 230-231) "[...] a monitoração com câmeras deve ser utilizada somente para meios específicos, com limite temporal, não pode mirar o comportamento dos trabalhadores e muito menos ser uma monitoração geral, devendo ser específica."

Além disso, outros requisitos têm sido colocados pela jurisprudência para a licitude desse procedimento, como a publicidade da monitoração, dando-se ciência aos trabalhadores dessa prática de monitoramento (por exemplo, por meio do regulamento da empresa, acordo ou convenção coletiva), bem como em razão da limitação dos locais de filmagem, como refeitórios e banheiros, conforme os arestos a seguir:

DANO MORAL. VIOLAÇÃO DA INTIMIDADE. A instalação de câmera filmadora no local de trabalho, sem comunicação prévia aos empregados, ain-

\footnotetext{
${ }_{16}$ ET Art. 20. Direción y control de la actividad laboral [...] 3. El empresario podrá adoptar las medidas que estime más oportunas de vigilancia y control para verificar el cumplimento por el trabajador de sus obligaciones y deberes laborales, guardando en su adopción y aplicación la consideración debida a su dignidad humana y teniendo en cuenta la capacidad real de los trabajadores disminuidos, en su caso.
} 
da que se trate de medida de segurança, ofende o direito à inviolabilidade da intimidade assegurado no inciso X do art. $5^{\circ}$, da Constituição da República, fazendo incidir a norma insculpida no inciso $\mathrm{V}$ do aludido dispositivo constitucional (SANTA CATARINA, 2002).

AGRAVO DE INSTRUMENTO. RECURSO DE REVISTA. DANO MORAL RECONHECIDO.

RATIFICAÇÃO. Nos termos do eg. Regional, revelando-se incontroversa a instalação de equipamentos câmeras de filmagem nas dependências dos banheiros de utilização dos empregados, mais especificamente na porta de entrada dos vasos sanitários e mictórios, tal situação, por si só, gera constrangimento moral e social, caracterizando o dano moral [...] Diante desta constatação, não se tem dúvida de que a instalação das aludidas câmaras configura prática de ato lesivo desrespeito à dignidade e intimidade do trabalhador que gerou constrangimento moral e social, caracterizando o dano. Basta imaginar que, ao ir ao banheiro, a fim de satisfazer suas necessidades fisiológicas, esteja sendo filmado, para conhecimento do patrão e demais interessados. Ainda que seja admitida a culpa da empresa contratada, não há como afastar a responsabilidade patronal, cuja culpa decorre da negligência de não ter monitorado a prestação de serviço contratado. $\mathrm{O}$ ato negligente permitiu a instalação de câmaras Verdadeiras ou falsas, não importa, porque a consequência é a mesma no ambiente de trabalho do reclamante, provocando, repita-se, constrangimento moral e social, além de ser vexatório [...] (BRASIL, 2005a).

No âmbito do Tribunal Superior do Trabalho, entende-se que a prática de monitoramento por câmeras de vídeo não viola a privacidade dos trabalhadores, estando esse procedimento dentro do uso do poder diretivo do empregador quando atende a critérios de razoabilidade, tendo por escopo a proteção do estabelecimento da empresa e o resguardo às pessoas que lá se encontram, buscando evitar a ocorrência de furtos e roubos, conforme decisão a seguir:

AGRAVO DE INSTRUMENTO - MINISTÉRIO PÚBLICO DO TRABALHO INSTALAÇÃO DE CÂMERAS DE VÍDEO DIREITO DE APRENDER E DE ENSINAR 1. O uso do poder diretivo do empregador atendeu a critérios de razoabilidade, tendo em vista que a instalação de câmeras de vídeo teve por fim a proteção do estabelecimento de ensino e das pessoas que lá se encontram, sejam alunos, sejam funcionários da instituição, com o intuito de evitar furtos e roubos. 2. Além disso, os direitos previstos no artigo 206, II, da Constituição de 88, quais sejam, liberdade de aprender, ensinar, pesquisar e divulgar o pensamento, a arte e o saber, não são vulnerados ou ameaçados pela instalação de câmeras de vídeo na portaria, na tesouraria e no estacionamento de instituição de ensino. (BRASIL, 2006).

Dessa maneira, entende-se que a adoção de tais procedimentos seria legítima ao empregador quando fundada em motivos relevantes que justificassem a adoção da medida e diante da impossibilidade da realização da vigilância por outros meios. Tal fiscalização deve ter como objetos o resguardo do patrimônio (SILVA; OLIVEIRA, 2007), bem como a preservação da integridade física das pessoas que circulam no estabelecimento empresarial, não podendo ter como foco a fiscalização direta dos atos do empregado com o escopo de espionar a conduta do trabalhador.

Além disso, é cristalino que o monitoramento por câmeras, além da publicidade quanto à adoção desse método de vigilância, deve excluir ambientes como 
banheiros, vestiários, áreas de alimentação e descanso, devendo ser limitado aos postos de trabalho ou aos locais de acesso à empresa.

\subsection{O monitoramento da correspondência eletrônica}

A internet tornou-se um dos mais importantes mecanismos de informação e troca de dados entre pessoas, bem como indispensável ferramenta em centros de pesquisa, em universidades e empresas. Da popularização da internet surgiram inúmeras novas frentes de uso para a rede: culturais, científicas e, também, na atividade laboral, tornando-se, rapidamente, instrumento de trabalho, utilizado pela maioria dos empregados das empresas da atualidade. Um dos mais utilizados recursos proporcionados pela internet no ambiente de trabalho é a correspondência eletrônica.

Em que pese se tratar de uma tecnologia avançada, o correio eletrônico é um meio de comunicação que não possibilita uma garantia absoluta de privacidade, pois a mensagem enviada pode, facilmente, ser interceptada e rastreada por meio de programas específicos, assim como se podem rastrear os sites percorridos pelo usuário e averiguar todo o histórico da "navegação" realizada na internet.

Como forma de coibir abusos por parte dos empregados e de evitar o uso indevido dessas novas tecnologias na relação de trabalho, a cada dia aumenta o número de empresas que adotam métodos de controle e fiscalização sobre os sistemas informáticos no ambiente de trabalho e, ao assim proceder, verifica-se, também, a ocorrência de conflitos envolvendo a utilização indevida do $e$-mail no serviço. Isso porque envolve a contraposição de duas situações tuteladas pelo direito, anteriormente abordadas nos dois casos analisados, quais sejam: o poder diretivo do empregador e a privacidade do empregado.

Em julgamento pioneiro sobre o assunto, que tem balizado os julgados posteriores, o TST analisou a questão em uma reclamação trabalhista movida por um empregado que utilizou o e-mail corporativo da empresa para enviar fotos de mulheres nuas a colegas. O processo, originário da Terceira Turma do TRT da $10^{a}$ Região (Brasília), reformou a sentença da $13^{\text {a }}$ Vara do Trabalho de Brasília, que afastou a justa causa aplicada pela empresa reclamada. A decisão de primeiro grau havia adotado como fundamento para descaracterizar a justa causa aplicada pela empresa a ilegalidade na obtenção da prova pelo empregador, qual seja, o rastreamento do e-mail. No entanto, o TRT entendeu que, na hipótese, não houve violação à privacidade do empregado, visto que o endereço eletrônico não era particular, mas da empresa (BRASIL, 2005b). Houve recurso pela parte; no julgamento pelo TST, a Primeira Turma reconheceu o direito de o empregador obter provas para a justa causa por meio do rastreamento do e-mail. Na decisão, o Relator, Ministro João Oreste Dalazen, asseverou que o empregador pode exercer de forma moderada, generalizada e impessoal o controle sobre o correio eletrônico, pois a natureza deste equivale a uma ferramenta de trabalho. Ademais, sustentou que "[...] o correio eletrônico corporativo não pode servir para fins estritamente pessoais, para o empregado provocar prejuízo ao empregador com o envio 
de fotos pornográficas, por meio do computador e provedor também fornecidos pela empresa." (BRASIL, 2005b). Por se tratar de uma decisão paradigma para tal situação de conflito, veja-se o teor da íntegra da referida decisão:

\section{PROVA ILÍCITA. "E-MAIL” CORPORATIVO. JUSTA CAUSA. DIVULGA-} ÇÃO DE MATERIAL PORNOGRÁFICO.

1. Os sacrossantos direitos do cidadão à privacidade e ao sigilo de correspondência, constitucionalmente assegurados, concernem à comunicação estritamente pessoal, ainda que virtual ("e-mail" particular). Assim, apenas o e-mail pessoal ou particular do empregado, socorrendo-se de provedor próprio, desfruta da proteção constitucional e legal de inviolabilidade.

2. Solução diversa impõe-se em se tratando do chamado "e-mail" corporativo, instrumento de comunicação virtual mediante o qual o empregado louva-se de terminal de computador e de provedor da empresa, bem assim do próprio endereço eletrônico que lhe é disponibilizado igualmente pela empresa. Destina-se este a que nele trafeguem mensagens de cunho estritamente profissional. Em princípio, é de uso corporativo, salvo consentimento do empregador. Ostenta, pois, natureza jurídica equivalente à de uma ferramenta de trabalho proporcionada pelo empregador ao empregado para a consecução do serviço.

3. A estreita e cada vez mais intensa vinculação que passou a existir, de uns tempos a esta parte, entre Internet e/ou correspondência eletrônica e justa causa e/ou crime, exige muita parcimônia dos órgãos jurisdicionais na qualificação da ilicitude da prova referente ao desvio de finalidade na utilização dessa tecnologia, tomando-se em conta, inclusive, o princípio da proporcionalidade e, pois, os diversos valores jurídicos tutelados pela lei e pela Constituição Federal. A experiência subministrada ao magistrado pela observação do que ordinariamente acontece revela que, notadamente o "e-mail" corporativo, não raro sofre acentuado desvio de finalidade, mediante a utilização abusiva ou ilegal, de que é exemplo o envio de fotos pornográficas. Constitui, assim, em última análise, expediente pelo qual o empregado pode provocar expressivo prejuízo ao empregador.

4. Se se cuida de "e-mail" corporativo, declaradamente destinado somente para assuntos e matérias afetas ao serviço, o que está em jogo, antes de tudo, é o exercício do direito de propriedade do empregador sobre o computador capaz de acessar à INTERNET e sobre o próprio provedor. Instater presente também a responsabilidade do empregador, perante terceiros, pelos atos de seus empregados em serviço (Código Civil, art. 932, inc. III), bem como que está em xeque o direito à imagem do empregador, igualmente merecedor de tutela constitucional. Sobretudo, imperativo considerar que o empregado, ao receber uma caixa de "e-mail" de seu empregador para uso corporativo, mediante ciência prévia de que nele somente podem transitar mensagens profissionais, não tem razoável expectativa de privacidade quanto a esta, como se vem entendendo no Direito Comparado (EUA e Reino Unido).

5. Pode o empregador monitorar e rastrear a atividade do empregado no ambiente de trabalho, em "e-mail" corporativo, isto é, checar suas mensagens, tanto do ponto de vista formal quanto sob o ângulo material ou de conteúdo. Não é ilícita a prova assim obtida, visando a demonstrar justa causa para a despedida decorrente do envio de material pornográfico a colega de trabalho. Inexistência de afronta ao art. $5^{\circ}$, incisos X, XII e LVI, da Constituição Federal. (BRASIL, 2005b).

Embora outras garantias à privacidade já estejam regulamentadas por lei, como, por exemplo, a proibição de revistas íntimas nas empregadas e a impossibilidade da exigência de teste de gravidez como condição à admissão no emprego, previstas 
pela Lei n. 9.799/99, não há norma que discipline a utilização dos meios informáticos nas relações de trabalho. Primeiramente, cumpre esclarecer que possui o empregador a faculdade de regular e estabelecer uma política de uso dos meios informáticos, pois, na relação de emprego, é ele quem determina a forma pela qual serão utilizadas as ferramentas de trabalho. Portanto, a internet e o correio eletrônico podem ser colocados à disposição do empregado com o único fim de desenvolver as atividades laborais, sendo perfeitamente lícito e admissível que a utilização desses recursos seja vedada para outros objetivos que não os relacionados ao trabalho. Tal prerrogativa do empregador está fundada no poder diretivo (HAINZENREDER JÚNIOR, 2009) anteriormente abordado, e também no seu direito de propriedade.

Além disso, há inúmeras justificativas que corroboram e tornam ainda mais compreensível a proibição da utilização dos meios informáticos para tarefas pessoais:

a) spam ou lixo eletrônico;

b) sobrecarga do sistema informático da empresa com demandas particulares,

c) recebimento e transmissão de determinados arquivos ou programas que podem constituir pirataria, punível de acordo com a legislação sobre direitos autorais;

d) responsabilidade civil do empregador, nos termos do artigo 932, III , do Código Civil, por danos materiais ou morais decorrentes de atos dos seus empregados;

e) possibilidade de "contaminação" do sistema da empresa ao receber vírus em mensagem pessoal;

f) utilização do correio eletrônico para fins pessoais pelo empregado leva ao desperdício de tempo e à considerável diminuição na produtividade do trabalhador.

Em contrapartida, há quem entenda que o monitoramento do e-mail não poderia ser aceito com base no princípio geral de direito da dignidade da pessoa humana, nos direitos da personalidade (vida privada, intimidade e inviolabilidade das comunicações), no princípio da boa-fé no contrato de trabalho, de forma que eventual prova obtida pelo empregador referente ao uso indevido do correio eletrônico pelo empregado, nessas circunstâncias, seria considerada prova ilícita (SILVEIRA NETO; PAIVA, 2006), afrontando, pois, o artigo 5 ${ }^{\circ}$ LVI, da CF. Ainda, poder-se-ia sustentar que a fiscalização dos e-mails do empregado consistiria em violação da privacidade de terceiros que, provavelmente, desconhecem as normas empresariais e não sabem que a mensagem enviada ao destinatário não goza de privacidade. Nessa situação, o direito de privacidade do remetente da mensagem, agente externo à política de fiscalização, seria infringido, uma vez que acreditava que o envio da informação somente seria transmitido ao destinatário. 
Todavia, em consonância com o entendimento adotado pelo TST no julgado anteriormente citado, não se concorda com essa posição. Em que pese não se discuta que os direitos à intimidade e à vida privada são aplicáveis em qualquer relação jurídica, estes não podem ser tratados a priori e de forma absoluta. Tal posição se fundamenta no fato de que, quando o $e$-mail é concedido exclusivamente como instrumento ou ferramenta de trabalho, não há que se falar em correspondência íntima passível de sigilo. O caráter estritamente profissional do e-mail, em regra, abstrai a ideia de proteção e privacidade (HAINZENREDER JÚNIOR, 2009).

Para que se estabeleça uma situação cristalina no ambiente de trabalho acerca do uso dos meios informáticos, é imprescindível que o empregador utilize uma política para regulamentar a prática de uso do correio eletrônico, esclarecendo que se trata de ferramenta exclusiva para o trabalho, proibindo a utilização para fins particulares, bem como advertindo, previamente, os empregados que haverá controle sobre tais instrumentos.

O próprio Tribunal Regional do Trabalho da $4^{\text {a }}$ Região, por meio da Portaria n. 2.316, de 04 de julho de 2001, disciplinou a utilização dos serviços de correio eletrônico e acesso à internet no seu âmbito interno. Entre os motivos justificadores da aludida Portaria está a utilização inadequada do correio eletrônico e do acesso à internet, arrolando como atividades consideradas inadequadas, quando não relacionadas a questões de conteúdo ocupacional do cargo do usuário, o acesso de páginas da internet; a participação em serviços de conversação (sites de chat); a cópia de arquivos da internet (download); e o acesso a sites de atividades comerciais. Da mesma forma, no artigo $4^{\circ}$, foi determinado que o uso da internet será monitorado pela Secretaria de Informática, mediante o emprego de ferramentas específicas, com a possibilidade de geração de relatórios e estatísticas como sites visitados, softwares e serviços utilizados, frequência e tempo de uso.

A possibilidade de monitoramento do correio eletrônico também é defendida por Simón (2000), porque entende que no ambiente de trabalho o sigilo de comunicação não é ilimitado. Preconiza que "[...] se o empregador forneceu um computador ao empregado, presume-se que este equipamento seja fundamental para a execução do serviço. Logo, com base no poder de direção, o empregador poderia checar as mensagens eletrônicas recebidas e enviadas pelos trabalhadores, pois é terceiro interessado." Não obstante adverte que se a empresa permite o uso do correio para fins particulares, em caso de checagem de mensagens, somente poderia se tornar conhecido o conteúdo do e-mail profissional, excluindo-se a verificação das mensagens pessoais. Tal procedimento seria possível por meio da criação de mecanismos de identificação de arquivos de separação de mensagens. Todavia, a autora reconhece que, mesmo os e-mails particulares dos trabalhadores, quando houver fundado receio da prática de atividades irregulares, poderão ser checados, uma vez que as liberdades públicas não se prestam ao "acobertamento" de ilicitudes.

A título exemplificativo, na Comunidade Europeia, são elencados princípios gerais aplicáveis ao monitoramento do correio eletrônico, quais sejam: 


\begin{abstract}
Princípio da necessidade (determina que o empregador deve avaliar se o monitoramento é necessário para um determinado fim, devendo priorizar métodos tradicionais de supervisão menos intrusivos na privacidade do trabalhador antes de monitorar as comunicações eletrônicas);

Princípio da finalidade (dispõe que os dados devem ser recolhidos para um fim especificado, explícito e legítimo, não podendo ser tratados para outra finalidade, como para monitorar o comportamento do trabalhador); Princípio da transparência (no sentido de que o empregador deverá explicitar aos trabalhadores sua política de monitoramento, a qual deverá conter elementos como, descrição da medida em que os meios de comunicação da empresa poderão ser usados para fins pessoais e razões e fins da vigilância); Princípio da legitimidade (qualquer operação de monitoramento não poderá violar direitos fundamentais do trabalhador);

Princípio da proporcionalidade (os dados pessoais devem ser adequados, pertinentes e não excessivos no que se refere ao fim especificado, excluindo-se a monitoramento geral de cada mensagem de correio eletrônico para além do que for necessário para garantir a segurança do sistema. (GUERRA, 2004, p. 303-306).
\end{abstract}

Segundo a The Eletronic Messaging Association (JOHNSON; PATTERSON, 2002 , p. 127), seria recomendado, inclusive, que os empregadores colocassem na tela do computador, a cada acesso do empregado à rede, uma mensagem de advertência sobre a política empresarial de uso da informática.

Importante contribuição para tentar elucidar o aspecto nevrálgico da legalidade da fiscalização das correspondências eletrônicas é trazida pela experiência norte-americana. Para esta, quando não há uma "razoável expectativa de privacidade", originada por intenções cristalinas da empresa de controle e verificação do correio eletrônico do empregado, pode-se sustentar a inexistência de direito à privacidade do empregado em suas comunicações no correio eletrônico fornecido pelo empregador. A jurisprudência americana entende que o empregado deva ter sua privacidade respeitada em determinadas zonas do lugar de trabalho, como vestiários ou banheiros, bem como que uma correspondência de natureza eminentemente pessoal deva ser protegida contra revistas do empregador, tanto é que os Tribunais dos EUA limitam a ação empresarial contra o que se chama "invasões altamente ofensivas da privacidade". Todavia, entende-se que, no ambiente de trabalho em que vigora uma política cristalina do uso do e-mail, não existe razoável expectativa de privacidade pelo obreiro, pois este possui plena ciência de que será realizada fiscalização nos instrumentos de trabalho de propriedade da empresa. Dessa maneira, é necessário haver uma posição de equilíbrio entre as razoáveis expectativas de privacidade do empregado e as justificativas de monitoramento e busca por parte do empresário (VARGAS; FRAGA; TELESCA, 2002, p. 128-129).

Cumpre referir que é fundamental estabelecer se em determinado ambiente de trabalho o empregado apresenta expectativa de privacidade no correio eletrônico ou se as normas contratuais delimitam claramente os limites de utilização da internet e do e-mail. Nessa última hipótese, o empregado, ao colocar sua força de trabalho à disposição do empregador, está se submetendo às regras do contrato, 
ficando limitado aos parâmetros nele avençados. Logo, uma vez pactuado, o uso das ferramentas de trabalho da empresa poderá ser restringido à atividade profissional, até porque se o empregador fornece aos empregados a utilização dos meios informáticos, certamente está buscando o alcance dos fins pelos quais foi constituída a atividade empresarial.

\section{Considerações finais}

Ao final deste estudo, verifica-se que o poder diretivo é o principal fundamento na defesa da possibilidade da adoção de práticas fiscalizatórias pelo empregador, como aquelas analisadas neste estudo. A faculdade de o empregador fiscalizar o trabalho do empregado objetiva a própria continuidade e segurança dos fins empresariais. Sob tal aspecto, o poder diretivo compreende a disponibilidade dos meios de produção em que está incluída a atividade do trabalhador. Portanto, quando a fiscalização se apresenta como condição imperativa para assegurar meios de resguardar a segurança na atividade empresarial, o poder de direção se torna imperioso.

Isso porque a $\mathrm{CF}$ de 1988 , no artigo $5^{\circ}$, XXII, garantiu o direito de propriedade. Assim, todos os meios de produção pertencentes ao empregador e que se materializam na empresa, no estabelecimento, no modo de produção, nas invenções, nas estratégias de atuação no mercado, no produto, etc. integram o objeto do seu direito de propriedade, sendo passíveis de proteção constitucional.

No entanto, é importante entender que na relação de emprego não é a pessoa do trabalhador o objeto do contrato, mas o labor e a soma de atividades que são desenvolvidas em favor da empresa. Portanto, o poder diretivo deve ser exercido nos limites da razoabilidade, ou seja, os critérios de vigilância necessitam estar em consonância com a dignidade do trabalhador, em especial, com o direito à privacidade, por força do artigo $5^{\circ}, \mathrm{X}$, da CF. Por se tratarem de direitos fundamentais, os direitos da personalidade do empregado não podem ser afastados, mesmo diante da relação de emprego, até porque a ela é aplicável o princípio da boa-fé.

Partindo dessas considerações sobre o tema da privacidade no contrato de trabalho, identifica-se, pois, que ambos os polos que envolvem a questão são objeto de tutela constitucional. Se, por um lado, os direitos da personalidade do empregado, que resguardam a sua privacidade no ambiente de trabalho, encontram guarida no artigo $5^{\circ}$, X, e XII da CF, a prerrogativa patronal de direção, nela incluindo a fiscalização das atividades laborais, também está protegida por um direito fundamental, qual seja, o direito de propriedade, nos termos do artigo $5^{\circ}$, XXII, da CF. Assim, considerando que a Constituição Federal há de ser interpretada de maneira a evitar contradições entre suas normas, estas devem ser analisadas como um todo unitário.

Considerando, pois, a inexistência de direito individual absoluto, nessas situações de conflitos examinadas, deve-se fazer a ponderação de princípios, de forma a mitigar ou relativizar, no caso concreto, as particularidades envolvidas, a fim de que se faça o respectivo sopesamento, de modo que se verifique qual princípio terá peso 
menor ou maior na situação específica. Tal critério hermenêutico de ponderação pode ser instrumentalizado por meio da proporcionalidade, composta por três máximas parciais: a adequação (estabelece a relação entre o meio empregado e o fim atingido), a necessidade (a norma aplicada deve considerar o meio mais benéfico ao destinatário) e a proporcionalidade em sentido estrito, que é a ponderação com base nos valores fundamentais do ordenamento jurídico. Por meio desses critérios, possibilitar-se-á concluir, dentro de determinadas circunstâncias dispostas no caso concreto, em relação aos procedimentos de revistas nos empregados, de fiscalização por câmeras de vídeo e de monitoramento de e-mails, se o direito à privacidade do empregado possui peso menor ou maior que o poder diretivo do empregador na situação analisada.

Em síntese, é crucial compatibilizar as novas necessidades empresariais, principalmente originadas pela tecnologia, com a tutela da personalidade do trabalhador, pretendendo-se preservar a harmonia no ambiente de trabalho sem abusos por parte do empregado nem invasões ofensivas à privacidade por parte do empregador.

\section{Referências}

ALBERTIN, Alberto Luiz. Comércio Eletrônico: modelos, aspectos e contribuições de sua aplicação. São Paulo: Atlas, 1990.

ANDRADE, Fábio Siebeneichler de. Considerações sobre o desenvolvimento dos direitos da personalidade e sua aplicação às relações de trabalho. Direitos fundamentais e justiça, Porto Alegre, v. 3, n. 6, p. 162-176, 2009.

ARAÚJO, Francisco Rossal de. A Boa-fé no Contrato de Emprego. São Paulo: LTr, 1996.

ARAUJO, Luiz Alberto David. A correspondência eletrônica do empregado (e-mail) e o poder diretivo do empregador. Revista de Direito Constitucional e Internacional, São Paulo, v. 10, n. 40, p. 102-103, jul./set. 2002.

BARROS, Alice Monteiro de. Curso de direito do trabalho. São Paulo: LTr, 2005.

BARROS, Alice Monteiro de. Proteção à intimidade do empregado. São Paulo: LTr, 1997.

BELIMONTE, Alexandre Agra. O controle da correspondência eletrônica no local de trabalho-Revista LTr, São Paulo, v. 68, n. 9, p. 1035-1036, set. 2004a.

BELIMONTE, Alexandre Agra. O monitoramento da correspondência eletrônica nas relações de trabalho. São Paulo: LTr, 2004b.

BITTAR, Carlos Alberto. Os direitos da personalidade. Rio de Janeiro: Forense Universitária, 1989. 
BOBBIO, Norberto. A Era dos Direitos. Rio de Janeiro: Campus, 1992.

BONAVIDES, Paulo. Curso de Direito Constitucional. 12. ed. São Paulo: Malheiros Editores, 2002.

BRASIL. Código Civil, Lei 10.406, de 10 de janeiro de 2002.

BRASIL. Consolidação das Leis do Trabalho. Decreto-Lei no 5.442, de 01.mai.1943

BRASIL. Constituição: República Federativa do Brasil de 1988. Brasília, DF: Senado Federal, 1988.

BRASIL. Tribunal Superior do Trabalho. AIRR n. 1830/2003-011-05-40. Relatora: Ministra Maria Cristina Irigoyen Peduzzi. Diário da Justiça, 10 ago. 2006.

BRASIL. Tribunal Superior do Trabalho. AIRR n. 1926/2003-044-03- 40.6. Relator: Juiz Ricardo Machado. Orgão Julgador: Terceira Turma. Decisão em 22 abr. 2005a.

BRASIL. Tribunal Superior do Trabalho. Proc. n. TST-RR-613/2000-013-10-00.7. Primeira Turma. Relator: Ministro João Oreste Dalazen. Orgão expedidor: Primeira Turma. Diário da Justiça, 10 jun. 2005b.

BYRUCHKO JUNIOR, Viktor. Ação civil pública. Revista do Ministério Público do Trabalho do Rio Grande do Sul/Procuradoria Regional do Trabalho da $4^{a}$ Região, Porto Alegre: PRT4, n. 1, p. 221-248, dez. 2006.

CAMINO, Carmem. Direito individual do trabalho. 4. ed. Porto Alegre: Síntese, 2004.

CANOTILHO, José Joaquim Gomes. Direito Constitucional e Teoria da Constituição. 3. ed. Coimbra: Almedina, 1999.

CATHARINO, José Martins. Compêndio de Direito do Trabalho. 3. ed. São Paulo: Saraiva, 1982. v. 1.

CAVERO, José Martinez de Pisón. El derecho a la intimidad en la jurisprudencia constitucional. Madrid: Civitas, 1993.

CORTES, Lourdes. Matéria especial abordou a revista íntima no ambiente de trabalho. Tribunal Superior do Trabalho, 17 jun. 2013. Disponível em: < http://www.tst. jus.br/noticias/-/asset_publisher/98Dk/contente/materia-especial-abordou-a-revista-intima-no-ambiente-de-trabalho >. Acesso em: 19 fev. 2014.

COSTA JUNIOR, Paulo José da. O direito de estar só: tutela penal da intimidade. 21. ed. São Paulo: RT, 1995.

COUTINHO, Aldacy Rachid. Poder Punitivo Trabalhista. São Paulo: LTr, 1999. 
DELGADO, Maurício Godinho. Curso de direito do trabalho. 4. ed. São Paulo: LTr, 2005.

DONEDA, Danilo César Maganhoto. Considerações iniciais sobre o banco de dados informatizados e o direito à privacidade. In: TEPEDINO, Gustavo (Org.). Problemas de direito civil-constitucional. Rio de Janeiro: Renovar, 2000.

DONEDA, Danilo César Maganhoto. Da privacidade à proteção de dados pessoais. Rio de Janeiro: Renovar, 2006.

ESCOLA NACIONAL DE FORMAÇÃO E APERFEIÇOAMENTO. Enunciado $n$. 15 da Escola Nacional de Formação e Aperfeiçoamento de Magistrados do Trabalho. Disponível em: <http://www.enamat.gov.br/>. Acesso em: 14 fev. 2014.

FACHINI NETO, Eugênio. Reflexões histórico-evolutivas sobre a constitucionalização do direito privado. In: SARLET, Ingo Wolfang (Org.). Constituição, direitos fundamentais e direito privado. 2. ed. Porto Alegre: Livraria do Advogado, 2006.

FACHIN, Luiz Edson. Análise crítica, construtiva e de índole constitucional da disciplina dos direitos da personalidade no Código Civil brasileiro: fundamentos, limites e transmissibilidade. Revista Jurídica, n. 362, p. 43-60, 2007.

FARIAS, Cibelly. O Sigilo Postal na Era da Comunicação Digital. Disponível em: <http://www.ter-sc.gov.br/sj/cjd/doutrinas/cibelly.htm>. Acesso em: 24 ago. 2003.

FERRAZ JUNIOR, Tércio Sampaio. Sigilo de dados: o direito à privacidade e os limites à função fiscalizadora do Estado. Cadernos de Direito Tributário e finanças públicas, São Paulo: RT, v. 1, p. 141-154, out./dez. 1992.

FOROUZAN, Behrouz A. Comunicação de Dados e Redes e Computadores. 3. ed. Porto Alegre: ArtMed, 2004.

FREITAS, Juarez. A interpretação sistemática do direito. 3. ed. São Paulo: Malheiros Editores, 2004.

GEIDIEL, José Antônio Peres. A irrenunciabilidade a direitos da personalidade pelo trabalhador. In: SARLET, Ingo Wolfang (Org.). Constituição, direitos fundamentais e direito privado. 2. ed. Porto Alegre: Livraria do Advogado, 2006.

GOMES, Orlando; GOTTSCHALK, Élson. Curso de direito do trabalho. 17. ed. Rio de Janeiro: Forense, 2005.

GONÇALVES, Simone Cruxên. Limites do Jus Variandi do Empregador. São Paulo: LTr, 1997. 
GOÑI SEIN, José Luis. La videovigilancia empresarial y la protección de datos personales. Madrid: Editorial Arazandi, 2007.

GRECO FILHO, Vicente. Tutela Constitucional das Liberdades: direitos individuais na Constituição de 1988. São Paulo: Saraiva, 1989.

GUERRA, Amadeu. A privacidade no local de trabalho. As novas tecnologias e o contrato dos trabalhadores através de sistemas automatizados uma abordagem ao código do trabalho. Coimbra: Almedina, 2004.

HÄBERLE, Peter. A dignidade humana como fundamento da comunidade estatal. In: SARLET, Ingo Wolfgang (Org.). Dimensões da dignidade: ensaios de filosofia do direito e direito constitucional. Porto Alegre: Livraria do Advogado, 2005.

HAINZENREDER JÚNIOR, Eugênio. Direito à privacidade e poder diretivo do empregador: o uso do e-mail no trabalho. São Paulo: Atlas, 2009.

HESSE, Konrad. A força normativa da constituição. Tradução Gilmar F. Mendes. Porto Alegre: Fabris, 1991.

JOHNSON, David; PATTERSON, Scott. Acces to and Disclosure of eletronic Mail on Company Computer Systems: A Tool Kit for Formulating Your Company's Policy. 1994. In: VARGAS, Luiz Alberto de et al. Direito do Trabalho Necessário. Porto Alegre: Livraria do Advogado, 2002.

LEWICK, Bruno. A privacidade da pessoa humana no ambiente de trabalho. Rio de Janeiro: Renovar, 2003.

LIMBERGER, Têmis. Direito e informática: o desafio de proteger os direitos do cidadão. In: SARLET, Ingo Wolfgang. Direitos fundamentais, informática e comunicação: algumas aproximações. Porto Alegre: Livraria do Advogado, 2007.

LIPPMANN, Ernesto. Do direito à privacidade do empregado, nos tempos da internet. Revista LTr, São Paulo: LTr, v. 62, n. 4, p. 483-486, abr. 1998.

LÔBO, Paulo Luiz Netto. Autolimitação do direito à privacidade. Revista Trimestral de Direito Civil, v. 34, abr./jun. 2008.

MAGANO, Octavio Bueno. Do poder diretivo na empresa. São Paulo: Saraiva, 1982.

MALLET, Estevão. Direitos da personalidade no direito do trabalho. Revista LTr, São Paulo, n. 68, p. 1309-1314, nov. 2004.

MARANHÃO, Délio; CARVALHO, Luiz. Direito do trabalho. 17. ed. Rio de Janeiro: Fundação Getulio Vargas, 1993. 
MARANHÃO, Délio et al. Instituições de direito do trabalho. 16. ed. São Paulo: LTr, 1996. v. 2.

MARTINS-COSTA, Judith. Os direitos fundamentais e a opção culturalista do novo Código Civil. In: SARLET, Ingo Wolfgang (Org.). Constituição, direitos fundamentais e direito privado. 2. ed. Porto Alegre: Livraria do Advogado, 2006.

MARTINS, Sérgio Pinto. Direito do Trabalho. 6. ed. atual. e ampl. São Paulo: Atlas, 1998.

MELGAR, Alfredo Montoya. Derecho del trabajo. 24. ed. Madrid: Editorial Tecnos, 2003.

MENDES, Gilmar. Curso de direito constitucional. 3. ed. rev. e atual. São Paulo: Saraiva, 2008.

MIGUEL, Carlos Ruiz. La configuración constitucional del derecho a la intimidad. España: Editoral Tecnos, 1995.

MIRANDA, Pontes de. Tratado de direito privado: parte especial. 3. ed. Rio de Janeiro: Borsoi, [entre 1970 e 1973].

MIRANDA, Rosângelo Rodrigues. A proteção constitucional da vida privada. São Paulo: Editora de Direito, 1996.

MIRANDOLA, Giovanni Pico della. A dignidade do homem. Tradução Luiz Feracine. São Paulo: GRD, 1988.

MUNARO, Franciel. Dignidade da pessoa humana e direito do trabalho, à luz da Constituição Federal de 1988. Revista de processo do trabalho e sindicalismo, Porto Alegre, v. 1, n. 1, p. 87, 2010.

NASCIMENTO, Amauri Mascaro. Curso de direito do trabalho. 19. ed. São Paulo: Saraiva, 2004.

NASCIMENTO, Amauri Mascaro. O novo âmbito do protecionismo do direito do trabalho. Revista LTr, São Paulo, n. 66-08, p. 916, ago. 2002.

NASCIMENTO, Amauri Mascaro. Princípios do direito do trabalho e direitos fundamentais do trabalhador. Revista LTr, São Paulo, n. 67-08/906, [s.d.].

NORONHA, Fernando. O direito dos contratos e seus princípios fundamentais: autonomia privada, boa-fé, justiça contratual. São Paulo: Saraiva, 1994.

OJIRI, Sérgio. O direito à privacidade na era da informática: algumas considerações. Revista jurídica Unijus, Uberaba, v. 8, n. 8, p. 99-105, 2005. 
OLEA, Manuel Alonso; BAAMONDE, Maria Emília Casas. Derecho del trabajo. 21. ed. Madrid: Civitas Ediciones, 2003.

OLIVEIRA NETO, Alberto Emiliano de; COELHO, Luciano Augusto de Toledo. Direito à Intimidade e à Privacidade - E-Mail do Empregado. Revista Justiça do Trabalho, n. 233, p. 39, maio 2003.

OLIVEIRA, Rogério Amigo de. Informática (provas e concursos). Rio de Janeiro: Elsevier, 2007.

ORGANIZAÇÃO INTERNACIONAL DO TRABALHO. Disponível em: < http:// www.oitbrasil.org.br/>. Acesso em: 14 fev. 2015.

PAESANI, Liliana Minardi. Direito e Internet - Liberdade de Informação, Privacidade e Responsabilidade Civil. São Paulo: Atlas, 2000.

PAIVA, Mário Antônio Lobato de. Comentários à Jurisprudência - E-mail - invasão de privacidade. Disponível em: < http://www.kplus.cosmo.com.br/materia. $\operatorname{asp} ? \mathrm{co}=90 \& \mathrm{rv}=$ Direito $>$. Acesso em: 10 set. 2003.

PAIVA, Mário Antônio Lobato de. Diretrizes para Utilização dos Meios Eletrônicos no Ambiente de Trabalho. Revista Justiça do Trabalho, n. 224, p. 58-64, ago. 2002.

PAIVA, Mário Antônio Lobato de. O E-mail como Instrumento de Divulgação Sindical. Disponível em: <http://www.direito.com.br/doutrina.ASP?O=1\&T+1877> . Acesso em: 21 maio 2002.

PAIVA, Mário Antônio Lobato de. O E-mail no Ambiente de Trabalho: o uso social do e-mail. Disponível em: <http://www.mct.gov.br/legis/consultoria-juridica/ artigos/e-mail-trabalho.htm.>. Acesso em: 07 ago. 2003.

PAIVA, Mário Antônio Lobato de. O Monitoramento do Correio Eletrônico no Ambiente de Trabalho. Revista Justiça do Trabalho, n. 227, p. 11-44, nov. 2002.

PAMPLONA FILHO, Rodolfo. Responsabilidade civil nas relações de trabalho e o novo Código Civil Brasileiro. Revista Trimestral de Direito Civil, ano 4, v. 13, p. 259-268, jan./mar. 2003. Disponível em: < http://www.fiscosoft.com.br/a/53xv/nocoes-conceituais-sobre-o-assedio-moral-na-relacao-de-emprego-rodolfo-pamplona-filho\#ixzz36pGjSYgt>. Acesso em: 19 fev. 2014.

PINTO DA SILVA, Guilherme Augusto. O direito à privacidade como limite ao poder diretivo do empregador: o caso da inviolabilidade do correio eletrônico. 2010. 42 p. Trabalho de Conclusão de Curso (Graduação em Ciências Jurídicas e Sociais)_ Pontifícia Universidade Católica do Rio Grande do Sul, Porto Alegre, 2010. Disponível em: <http://www3.pucrs.br/pucrs/files/uni/poa/direito/graduacao/tcc/tcc2/trabalhos2010_2/guilherme_silva.pdf $>$. Acesso em: 01 jul. 2011. 
ROMITA, Arion Sayão. A subordinação no contrato de trabalho. Rio de Janeiro: Forense, 1979.

RIO GRANDE DO SUL (Estado). Tribunal Regional do Trabalho da $4^{\mathrm{a}}$ Região. Acórdão n. 0001003-57.2010.5.04.0016 RO. Relator: Desembargador José Felipe Ledur. Órgão julgador: Primeira Turma. Publicação em 05 mar. 2012a.

RIO GRANDE DO SUL (Estado). Tribunal Regional do Trabalho da $4^{\mathrm{a}}$ Região. Acórdão do Processo n. 0041500-82.2006.5.04.0104. Relatora: Juíza Eurídice Josefina Bazo Tôrres. Órgão julgador: Primeira Turma Participam: Pedro Luiz Serafini, José Felipe Ledur. Porto Alegre, 03 jul. 2007.

RIO GRANDE DO SUL (Estado). Tribunal Regional do Trabalho da $4^{a}$ Região. $R O$ 0000078-51.2011.5.04.0008. Relator: Desembargador Marcelo Gonçalves de Oliveira. Órgão julgador: Sétima Turma. Participaram do julgamento: Desembargador Marçal Henri dos Santos Figueiredo, Juiz Convocado João Batista de Matos Danda. Julgamento em 23 maio 2012b.

RIO GRANDE DO SUL (Estado). Tribunal Regional do Trabalho da $4^{\mathrm{a}}$ Região. $2^{\mathrm{a}}$ Vara do Trabalho de Cachoeirinha. Acórdão do processo 0000162-28.2013.5.04.0252 (RO). Relatora: Desembargadora Flávia Lorena Pacheco. Participam: Ricardo Hofmeister de Almeida Martins Costa, Herbert Paulo Beck. Decisão em 30 abr. 2014.

RIO GRANDE DO SUL (Estado). Tribunal Regional do Trabalho da $4^{\mathrm{a}}$ Região. $15^{\mathrm{a}}$ Vara do Trabalho de Porto Alegre. Acórdão do processo n. 0000266-86.2012.5.04.0015 (RO). Relator: Desembargador Francisco Rossal de Araújo. Participam: Juraci Galvão Júnior, Angela Rosi Almeida Chapper. Decisão em 22 ago. 2013.

RODRIGUEZ, Américo Plá. Princípios de Direito do Trabalho. São Paulo: Editora LTr, 1997.

RUARO, Regina Linden. O conteúdo essencial dos direitos fundamentais à intimidade e à vida privada na relação de emprego: o monitoramento do correio eletrônico pelo empregador. In: SARLET, Ingo Wolfgang (Org.). Direitos fundamentais, informática e comunicação: algumas aproximações. Porto Alegre: Livraria do Advogado, 2007.

RUSSOMANO, Mozart Victor. Curso de Direito do Trabalho. 5. ed. Curitiba: Juruá, 1995.

SANTA CATARINA (Estado). Tribunal Regional do Trabalho da $12^{\mathrm{a}}$ Região. $R O \mathrm{n}$. 00825-2001-008-12-00-9. Relatora: Juíza Maria de Lourdes Leiria. Órgão julgador: Terceira Turma. Decisão em 26 nov. 2002.

SARLET, Ingo Wolfgang. A eficácia dos direitos fundamentais. 4. ed. rev. e atual. Porto Alegre: Livraria do Advogado, 2004. 
SARLET, Ingo Wolfgang. As dimensões da dignidade da pessoa humana: construindo uma compreensão jurídico-constitucional necessária e possível. In: SARLET, Ingo Wolfang (Org.). Dimensões da dignidade: ensaios de filosofia do direito e direito Constitucional. Porto Alegre: Livraria do Advogado, 2005.

SARLET, Ingo Wolfgang. Dignidade da pessoa humana e direitos fundamentais na Constituição Federal de 1988. 6. ed. rev. e atual. Porto Alegre: Livraria do Advogado, 2008.

SILVA, Carlos Junior; OLIVEIRA, Lourival José. Do monitoramento no ambiente de trabalho com a instalação de Câmeras. Revista de Direito Público, Londrina, v. 2, n. 2, p. 91-114, maio/ago. 2007.

SILVA, José Afonso da. Curso de Direito Constitucional Positivo. 9. ed. São Paulo: Malheiros, 1994. SILVA, José Afonso da. Curso de direito constitucional positivo. 27. ed. São Paulo: Malheiros, 2006.

SILVEIRA NETO, Antônio; PAIVA, Mário Antônio Lobato de. A Privacidade do Trabalhador no Meio Informático. Disponível em: < http://www.mct.gov.br/legis/consultoria-juridica/artigos/informática-tecnologia.htm > . Acesso em: 23 jan. 2006.

SIMÓN, Sandra Lia. A Proteção Constitucional da Intimidade e da Vida Privada do Empregado. São Paulo: LTr, 2000.

SOUZA, Mauro César Martins de. E-Mail (...NET) na Relação de Emprego: Poder Diretivo do Empregadpr (Segurança) \& Privacidade do Empregado. Revista Justiça do Trabalho, n. 202, p. 7-23, out. 2002.

SUSSEKIND, Arnaldo et al. Instituições de Direito do Trabalho. 16. ed. São Paulo: Editora LTr, 1996. v. 1 e 2.

SZANIAWSKI, Elimar. Direitos de personalidade e sua tutela. 2. ed. São Paulo: Revista dos Tribunais, 2005.

TEIXEIRA, Eduardo Didonet; HAEBERLIN, Martin. A proteção da privacidade: aplicação na quebra do sigilo bancário e fiscal. Porto Alegre: Fabris, 2005.

TEPEDINO, Gustavo. A tutela da personalidade no ordenamento civil-constitucional brasileiro. In: TEPEDINO, Gustavo. Temas de direito civil. 3. ed. Rio de Janeiro: Renovar, 2004.

UNIDOS PELOS DIREITOS HUMANOS. A declaração universal dos direitos do homem. Disponível em: <http://www.humanrights.com/pt/what-are-human-rights/ universal-declaration-of-human-rights.html >. Acesso em: 14 fev. 2014.

VARGAS, Luiz; FRAGA, Ricardo Carvalho; TELESCA; Maria Madalena. Direito do Trabalho Necessário. Porto Alegre: Livraria do Advogado, 2002. 
VILHENA, Paulo Emílio Ribeiro de. Relação de Emprego - Estrutura Legal e Supostos. 2. ed. São Paulo: Editora LTr, 1999.

WARREN, Samuel D.; BRANDEIS, Louis D. The right to privacy. Harvard Law Review, v. 4, n. 5, dez. 1890.

WEBER, Thadeu. Autonomia e dignidade da pessoa humana em Kant. In: SARLET, Ingo Wolfgang; MOLINARO, Carlos Alberto (Coord.). Direitos fundamentais \& justiça, Porto Alegre: HS Editora, v. 3, n. 9, p. 232-259, out./dez. 2009.

ZANOTELLI, Maurício. Direito e diferença: a reconstrução jurídica da dignidade da pessoa humana. 2010. Dissertação (Mestrado em Direito Público)-Universidade do Vale do Rio dos Sinos, São Leopoldo, 2010.

Data da submissão: 10 de julho de 2014 Avaliado em: 17 de outubro de 2014 (Avaliador A) Avaliado em: 9 de setembro de 2014 (Avaliador B) Avaliado em: 15 de setembro de 2014 (Avaliador C) Aceito em: 21 de julho de 2015 